10.
Historia del Derecho chileno 

Revista de Derecho

de la Pontificia Universidad Católica de Valparaíso

XXXVI (Valparaíso, Chile, 2011, $1^{\text {er }}$ Semestre)

[pp. 619-663]

\title{
El protagonismo político del Poder JUDICIAL ENTRE LOS AÑOS 1965 Y 1973
}

["The Political Prominence of the Judiciary Between 1965 and 1973"]

\author{
Andrés Amunátegui ECheverRía* \\ Universidad de los Andes, Chile
}

\begin{abstract}
Resumen
Los acontecimientos histórico-políticos que vivió Chile durante los gobiernos de Eduardo Frei y Salvador Allende determinaron una progresiva intervención del Poder Judicial en la Política, en la búsqueda de la protección del Estado de Derecho y de sus prerrogativas constitucionales. En el presente trabajo se analiza el modo en que tal intervención se produjo y sus consecuencias.

$$
\text { Palabras Clave }
$$

Eduardo Frei M. - Salvador Allende Unidad Popular - Poder Judicial - Corte Suprema.
\end{abstract}

\begin{abstract}
The historical-political events occurred in Chile during the governments of Eduardo Frei and Salvador Allende caused a progressive intervention of the Judiciary in Politics in order to protect the Rule of Law and its constitutional prerogatives. This paper analyzes the way said intervention was conducted and its consequences.

KEYWORDS

Eduardo Frei M. - Salvador Allende - Unidad Popular - Judiciary - Supreme Court.
\end{abstract}

[RECIBIDO el 6 y APROBADo el 29 de abril de 2011].

* Profesor de la Facultad de Derecho de la Universidad de los Andes; doctorando en Derecho. Dirección postal: Avenida San Carlos de Apoquindo 2200, Santiago, Chile. Correo electrónico: aamunategui@miuandes.cl 


\section{Planteamiento de la Cuestión}

Que la función judicial es una actividad apolítica y que los jueces sólo dictan sus sentencias en base al estricto mérito del proceso, es una afirmación frecuente entre los miembros del Poder Judicial. Más aun, esta apoliticidad de la judicatura es vista por la ciudadanía como una garantía de independencia e imparcialidad respecto de los otros poderes del Estado.

Sin embargo, el principio de separación de poderes ha vivido crisis innumerables a los largo de la historia, cuando las competencias de unos y otros se confunden, o bien, cuando alguno de ellos pretende mayores poderes que los que el ordenamiento jurídico le reconoce.

En nuestra historia reciente, la Corte Suprema fue forzada a defender su independencia y prerrogativas Constitucionales en la arena política, frente a los ataques recibidos durante el gobierno de la Unidad Popular, luego de un evolutivo proceso de radicalización que comenzó bajo la presidencia de Eduardo Frei Montalva.

Hubo un intento del Ejecutivo de transformar la judicatura en cauce del establecimiento de un "nuevo orden” político. Y si bien el máximo Tribunal concordaba con que era necesario que el derecho se pusiera al día con el avance de las ciencias, ello no podía significar arrasar con todo los principios establecidos, en un afán por prescindir de todo lo que había, para construir lo que vendría ${ }^{1}$.

En 1972, el presidente de la Corte Suprema, Ramiro Méndez Brañas, denunciaba el intento por infiltrar al Poder Judicial, y las maniobras por "arrastrar a los integrantes del Poder Judicial a las violentas luch as de la politica contingente" 2 . Por su parte, el presidente de la República, Salvador Allende, en entrevista a Regy Debray ${ }^{3}$, criticaba la "justicia de clases" que impartía la Corte Suprema; acusación que compartía el entonces presidente del Consejo de Defensa del Estado, Eduardo Novoa Monreal, quien agregaba que el máximo Tribunal representaba a los sectores más conservadores de la sociedad chilena, y que su trabajo estaba obstaculizando el cumplimiento del programa de gobierno. Decía: "Dicho poder, particularmente la Corte Suprema, es un incondicional defensor del status social, económico y politico

${ }^{1}$ Méndez Braña, Ramiro, Memoria leida por el Presidente de la Excma. Corte Suprema en la Sesión Inaugural del año 1970, en Revista de Derecho, Jurisprudencia y Ciencias Sociales y Gaceta de los Tribunales, 67 (Santiago, 1970) 1, pp. v-xli.

${ }^{2}$ Méndez Braña, Ramiro, Memoria leida por el Presidente de la Excma. Corte Suprema en la Sesión Inaugural del año 1972, en Revista de Derecho, Jurisprudencia y Ciencias Sociales y Gaceta de los Tribunales, 69 (Santiago, 1972) 1-2, p. xv.

${ }^{3}$ Véase "Entrevista de Salvador Allende y Regis Debray", en Punto Final (Santiago, 16 de mayo de 1971). 
vigente, y reprueba a quienes luchan por los cambios sociales"4. Un enfático Ramiro Méndez en el discurso inaugural del año judicial de 1970 se defendió afirmando: "Es absurdo decir que la justicia entre nosotros es una justicia de clase, defensora incondicional del status social vigente. Ella es simplemente la aplicadora de las leyes que rigen la República"'.

Más tarde, se acusaría al máximo Tribunal de ideologizar sus fallos, y de constituir un auténtico frente interno junto a la Contraloría y al Congreso, en contra del Ejecutivo ${ }^{6}$.

Las críticas y denuncias de los altos magistrados dejaban al descubierto el fenómeno que se estaba viviendo en Chile desde mediados de la década de 1960, el que no pudo dejar a la judicatura indiferente.

El tenor de las exposiciones de sus máximos representantes, así como los innumerables oficios intercambiados con el presidente de la República, dan cuenta de la necesidad que tuvo este tercer poder del Estado de defender su independencia, entrando al análisis de la coyuntura política y del papel que en esa encrucijada debía cumplir. Los jueces, en tanto miembros de la comunidad, no podían mantenerse completamente al margen de los sucesos que estaban ocurriendo en el Chile de esos años.

El presidente de la Corte Suprema, en su discurso de inauguración del año judicial en marzo de 1973, recalcaba que era tarea del legislador la modernización del derecho, y no era el intérprete el llamado a incorporar los cambios sociales, resaltando que el estado de derecho consistía precisamente en el respeto efectivo a los derechos y deberes que el sistema democrático otorga a los Poderes Públicos, a quienes ejercen su autoridad y a los ciudadanos ${ }^{7}$.

Fue notorio que durante los tres años de gobierno de Allende, el Poder Judicial fue incursionando paulatinamente en el campo político, agudizando su crítica y la dureza de sus términos. Sin embargo, esta evolución no obedecía a un intento de ejercer competencias no reconocidas por la Constitución, ni a un deseo de obtener una mayor cuota de poder. En cambio, resulta evidente que la motivación del máximo tribunal era mantener la independencia necesaria para la administración de justicia, que, por razones netamente políticas, estaban siendo gravemente coartadas.

${ }^{4}$ Novoa Monreal, Eduardo, El difícil camino de la legalidad, en Revista de la Universidad Técnica del Estado, 7 (Santiago, 1972), p. 25.

${ }^{5}$ Méndez, Ramiro, cit. (n. 1), p. xviii.

${ }^{6}$ Ministro de Justicia, “Oficio s/n de 14 de julio de 1972”, en Consejo General de la Orden de Abogados: Antecedentes Histórico Jurídicos: Años 1972-1973 (Santiago, Editorial Jurídica de Chile, 1980), p. 22.

${ }^{7}$ Urrutia Manzano, Enrique, Memoria leida por el Presidente de la Excma. Corte Suprema en la Sesión Inaugural del año 1973, en Revista de Derecho, Jurisprudencia y Ciencias Sociales y Gaceta de los Tribunales, 70 (Santiago, 1973), pp. xxii a xxiv. 
En efecto, en un sector ligado al Gobierno, se había impuesto la tesis que sostenía que desde el Poder Judicial se había acordado colaborar con la tarea de la oposición política, intentando siempre exhibir al Ejecutivo como transgresor de la ley ${ }^{8}$.

Esto justificaría la consecuente y soterrada campaña de desprestigio iniciada contra la judicatura, de la cual se quejaban sus máximos representantes, al ser acusados de administrar una justicia cara, lenta y que amparaba a grupos de fortuna'.

Más aún, el presidente de la República sostenía que algunos sectores del Poder Judicial, en especial de su máximo Tribunal, manifestando una incomprensión de las transformaciones sociales que vivía el país, y de los anhelos de justicia social de grandes masas postergadas, habían puesto tanto la ley como los procedimientos judiciales, "al servicio de los intereses afectados por las transformaciones, con desmedro y daño del régimen institucional y de la pacifica y regular convivencia de las diversas jerarquias y autoridades" ${ }^{10}$.

La pugna que comenzó a evidenciarse entre el poder Judicial y el Ejecutivo, adoptó un esquema de ataques y respuestas. Así, frente al fenómeno de la requisición de empresas por parte del Ejecutivo, la Corte respondió al subsumir estas conductas bajo el tipo penal de la usurpación. Existe discusión acerca de la procedencia de la aplicación de tales normas penales, pero lo cierto es que ésta fue la fórmula que utilizó la Corte para dar protección a los particulares en aquellos casos en los que estos sentían su derecho de propiedad conculcado ${ }^{11}$.

Adicionalmente, la Corte habría concedido un sinnúmero de medidas precautorias que obstaculizaban algunas de las actuaciones del Ejecutivo respecto de propiedades o empresas de particulares.

Frente a esta situación, la administración optó por calificar el mérito y oportunidad del otorgamiento de la fuerza pública solicitada por los jueces para el necesario cumplimiento de sus resoluciones judiciales. La norma legal

\footnotetext{
${ }^{8}$ Novoa Monreal, Eduardo, Los resquicios legales. Un ejercicio de lógica jurídica (Santiago, Editorial Bat, 1992), p. 68.

${ }^{9}$ Méndez Braña, Ramiro, Memoria leida por el Presidente de la Excma. Corte Suprema en la Sesión Inaugural del año 1971, en Revista de Derecho, Jurisprudencia y Ciencias Sociales y Gaceta de los Tribunales, 68 (Santiago, 1971) 1-2, pp. v-xxxii.

${ }^{10}$ Presidente de la República, “Oficio s/n de 12 de junio de 1973", en Consejo General de la Orden de Abogados: Antecedentes Histórico Jurídicos: Años 1972-1973 (Santiago, Editorial Jurídica de Chile, 1980), p. 105.

${ }^{11}$ Cortés Alvear, Loreto, La Corte Suprema de Justicia y sus relaciones con el Poder Ejecutivo durante el gobierno de la Unidad Popular (1970-1973) (Tesis para optar al grado de Licenciada en Ciencias Jurídicas Pontificia Universidad Católica de Chile, Santiago, inédito, disponible en Biblioteca Facultad de Derecho Pontificia Universidad Católica de Chile, 1992), pp. 3-4.
} 
era clara. No era papel del ejecutivo la calificación de tales solicitudes; sin embargo se alegaba que siendo la seguridad nacional de su responsabilidad, éste estaba facultado para discernir si el cumplimiento de una determinada resolución judicial podía implicar una alteración al orden social, cuestión que debía evitarse. Tal fue la precisa instrucción entregada por el Ministerio del Interior a los Intendentes Regionales, a cuyo cargo estaba la fuerza pública, mediante la Circular Confidencial № 3 de 19 de enero de 1973, firmada por el general Carlos Prats González ${ }^{12}$.

Estas pugnas fueron agudizándose a niveles extremos, como lo demuestra el nutrido intercambio de oficios entre la Corte Suprema y el Ejecutivo, que llevaron, incluso, a la Corte a declarar que el presidente de la República había invadido un campo jurídico que constitucionalmente le estaba vedado; que éste había adoptado una posición militante contra el órgano jurisdiccional superior del país; que la máxima autoridad del país desconocía las atribuciones del Poder Judicial; y que la garantía de prescindencia del jefe supremo de la Nación se había desvanecido "cuando el presidente acogió las erróneas insinuaciones de sus presuntos colaboradores y asumió plena militancia partidaria en la ofensiva desencadenada contra un Poder que, sin desvirtuar su oficio, no puede someterse a las exigencias o deseos de cualquier otro de los Poderes del Estado"13.

No sorprende entonces, que la Corte Suprema diera su apoyo al Gobierno asumido por los militares, en tanto estos le aseguraron el fiel respeto de su independencia y el diligente cumplimiento de sus resoluciones judiciales ${ }^{14}$ : "En verdad, el Gobierno elegido en 1970, con sus desaciertos y su constante violación de la ley de manera manifiesta, tanto en su letra como en su espiritu, habia perdido ya la legitimidad obtenida con su elección por el Congreso $\mathrm{Na}$ cional, y, por el contrario, legitimaba así, a su vez, los sucesos ocurridos en el recordado once de septiembre"15.

A partir del análisis del contexto histórico que vivía nuestro país desde el gobierno de Eduardo Frei Montalva y hasta el 11 de septiembre de 1973, y a través del estudio de diversos fallos de la Corte Suprema de Justicia, in-

${ }^{12}$ Echeverría, Andrés - Frei, Luis (editores), La lucha por la juridicidad en Chile 1970-1973 (Santiago, Editorial del Pacífico, 1974, III, p. 154.

${ }^{13}$ Corte Suprema de Justicia, "Oficio de 25 de junio de 1973" en Consejo General de la Orden de Abogados: Antecedentes Histórico Jurídicos: Años 1972-1973 (Santiago, Editorial Jurídica de Chile, 1980), p. 106.

${ }^{14}$ Corte Suprema de Justicia, “Oficio No 3182”, en Consejo General de la Orden de Abogados: Antecedentes Histórico Jurídicos: Años 1972-1973 (Santiago, Editorial Jurídica de Chile, 1980), pp. 177 y 178.

${ }^{15}$ Urrutia Manzano, Enrique, Memoria leida por el Presidente de la Excma. Corte Suprema en la Sesión Inaugural del año 1974, en Revista de Derecho, Jurisprudencia y Ciencias Sociales y Gaceta de los Tribunales, 71 (Santiago, 1974), p. 21. 
tentaremos mostrar que el máximo Tribunal sí tuvo una noción de realismo político acerca de lo que estaba ocurriendo en nuestro país, e intentó salvaguardar la institucionalidad democrática y el derecho de propiedad, frente a la ejecución del programa de gobierno de la Unidad Popular.

\section{EL CONTEXTO HISTÓRICO}

\section{La revolución en libertad.}

Los años sesenta fueron una década marcada por los afanes revolucionarios impulsados por algunos sectores de la sociedad, tanto en el ámbito económico, social, como en el político. Los nuevos proyectos que de allí surgieron "proponían la implantación de transformaciones globales a partir de una intervención directa y planificada desde el Estado" 16 .

El objetivo planteado era obtener el cambio de las estructuras tradicionales desde el aparato Estatal, intentando una "transformación rápida, decidida y cabal de los órdenes establecidos, deviniendo en un giro completo en las conciencias y paradigmas que sustenta una sociedad determinada"17.

Es lo que Mario Góngora llamó el comienzo de la época de las planificaciones globales, cuyo objetivo fue el intento de salir del subdesarrollo mediante la acción concertada del Estado con todos los sectores progresistas de la sociedad, mediante un proceso inducido, y en el que la Democracia Cristiana jugó un rol relevante, al transformarse en los años 50 en un partido de masas $^{18}$.

Se instaló en el ambiente como un verdadero imperativo de realizar una transformación drástica y definitiva de las instituciones establecidas, sujeta al dilema de la vía legal o de la vía violenta para su ejecución ${ }^{19}$.

Eduardo Frei Montalva fue el primero en plantear la llamada "Revolución en Libertad", cuyos objetivos más importantes los resumía en "la necesidad de promover el desarrollo económico acelerado, de democratizar la vida socialy económica, y de impulsar reformas básicas que hagan realidad la participación popular en las decisiones más fundamentales del Estado y la Comunidad. Estos

${ }^{16}$ Correa, Sofía y otros, Historia del siglo XX chileno. Balance Paradojal. (4a edición, Santiago, Editorial Sudamericana, 2008), p. 239.

${ }^{17}$ Correa, Sofía, cit. (n. 16).

${ }^{18}$ Góngora del CAmpo, Mario, Ensayo histórico sobre la noción de Estado en Chile en los siglos XIX y XX (7a edición, Santiago, Editorial Universitaria, 1998), pp. 280 a 285.

${ }^{19}$ Bravo Lira, Bernardino, Presidente y Estado de Derecho en Chile. Estudio Histórico-Institucional, en Revista de Derecho y Jurisprudencia, 90 (Santiago, 1993) 2, p. 85. 
objetivos implican un conjunto de cambios de fondo en la estructura del pais, sin los cuales su realización es imposible"20.

Pero esta revolución no sería sólo obra de un grupo de ideólogos, sino que se había concebido como parte de una planificación impulsada decididamente por el Ejecutivo. Así, apoyados en el análisis estructuralista efectuado por la CEPAL, se postulaba que la "única alternativa viable de desarrollo de los países latinoamericanos radicaba esencialmente en la transformación de aquellos sectores que, fundados en una lógica tradicional, impedían la modernización de la economía y, consecuencialmente, de la sociedad"21.

Se comenzaba así a producir la polarización social, en tanto se responsabilizaba a un sector de la sociedad de los atrasos que vivía el país, proponiendo su reforma total.

En este contexto, se entiende la prioridad que le asignó el gobierno de Frei Montalva a la profundización de la reforma agraria, con la incorporación de la causal de expropiación por extensión del predio (latifundios), en reemplazo de aquella que sólo la autorizaba en caso de tierras mal explotadas (Alessandri); la de tierras abandonadas, las pertenecientes a personas jurídicas, entre otras ${ }^{22}$.

Aun persiste el debate sobre los resultados efectivos de esta reforma. Para algunos, puso fin al orden hacendal en el cual se había sustentado históricamente el orden social y político del país, lo que habría determinado una postura cada vez más confrontacional e impetuosa de la elite tradicional, al verse despojada de uno de los fundamentos básicos de su poder: la hacienda y su orden jerárquico ${ }^{23}$.

Para otros, el impulso reformista en el campo demostró un afán constructivista para dar forma a un nuevo tipo de sociedad radicalmente distinta a la tradicional chilena, sin una efectiva consideración de la realidad nacional, constituyendo un tipo de pequeña propiedad familiar sometida a controles, obligaciones, prohibiciones y cooperativas no voluntarias ${ }^{24}$.

Un poco más allá, hay quienes sostienen que esta reforma buscaba la destrucción de la derecha y el socavamiento de la influencia que ésta tenía en

${ }^{20}$ Frei Montalva, Eduardo, Proyecto sobre Leyes Normativas, en Politica y Espiritu, 287 (Santiago, 1964), p. 53

${ }^{21}$ Correa, Sofía, cit. (n. 16), p. 246.

${ }^{22}$ Para una análisis detallado de la legislación de reforma agraria durante este período puede consultarse: Brahm García, Enrique, Propiedad sin libertad: Chile 19251973. Aspectos relevantes en el avance de la legislación socializadora (Santiago, Universidad de los Andes, 1999), pp. 182 a 196.

${ }^{23}$ Correa, Sofía, cit. (n. 16), p. 250.

${ }^{24}$ Brahm García, Enrique, Propiedad sin libertad, cit. (n. 22), p. 193. 
el campo, lo que explicaría la "alteración profunda de la vida social y política en todas las provincias rurales" 25 .

Góngora sostiene que tratándose de una reforma substancial que buscó modificar la estructura social del campo chileno, en un intento por crear una clase media campesina independiente, conservadora y próspera, con mentalidad empresarial para aumenta la productividad del campo, aquello suponía un cambio cultural que "habría necesitado un largo tiempo y una política consistente para prosperar"26.

Éstos fueron los aspectos considerados como rupturistas en el programa de Frei, lo que para algunos demostraría que su proyecto apuntaba a provocar una reorganización de la sociedad, sin sujeción a los parámetros y límites fijados por los intereses de la clase dominante de entonces ${ }^{27}$.

Sin embargo, la intención de obtener la solución a los desequilibrios económicos y la reactivación de la economía por la vía de las reformas estructurales parecieron no ser suficientes para un sector aún más extremo.

En efecto, la revista jesuita Mensaje se convirtió en el instrumento que recogió la crítica que reclamaba la frustración de la revolución planteada, que "se hubiera seguido viviendo y conviviendo con un sistema jurídico y constitucional que seguía siendo expresión de la forma de sociedad controlada por las 'clases dominantes' que estaba destinada a desaparecer"28.

La Revolución en Libertad propuesta por Frei determinó el inicio de una etapa de conflicto en Chile, que involucró a los partidos políticos, los que perdieron su capacidad de entendimiento; a parte de la jerarquía de la Iglesia Católica, que promovió abiertamente las ideas reformistas; a la sociedad misma, evidenciando un verdadero enfrentamiento de clases; y, en fin, al propio Gobierno, a la juventud y a la prensa.

Así las cosas, durante la segunda mitad de la década del 60, desde ambos extremos del mundo político comienzan los cuestionamientos al sistema político democrático. Desde la izquierda "se trató de una 'descalificación derivada' en cuanto se imputa al orden democrático burgués o formal el carácter de custodio del sistema económico capitalista, cuya sustitución por el socialismo se plantea como condición de existencia de una 'democracia real"; en tanto que, desde la derecha, el rechazo al capitalismo se percibió "como una amenaza a los valores e intereses fundamentales del sector [...] porque

${ }^{25}$ Cardemil, Alberto, El camino de la utopia. Alessandri, Frei, Allende. Pensamiento y obra (Santiago, Editorial Andrés Bello, 1997), pp. 225 y 236.

${ }^{26}$ Góngora, Mario, cit. (n. 18), pp. 286 y 287.

${ }^{27}$ Moulian Emparanza, Tomás, Fracturas: De Pedro Aguirre Cerda a Salvador Allende (1938-1973) (Santiago, LOM Ediciones, 2006), p. 223.

${ }^{28}$ Brunner, José Joaquín, Comentarios nacionales, en Mensaje, 1 (Santiago, 1968), p. 4. 
se desconfía de su capacidad de defender el orden económico-social vigente y se comienzan a percibir los riesgos de la alternancia en el gobierno"29.

$\mathrm{Al}$ mismo tiempo, esta radicalización de las posiciones políticas determinaron la aparición de nuevas formas y procedimientos, entre los que se cuentan las tomas de terrenos urbanos y de fundos, así como las ocupaciones de fábricas, lo que generó un clima de incertidumbre y confusión que con frecuencia desembocó en violentas pugnas provocadas desde uno y otro sector $^{30}$.

\section{Vía chilena al socialismo.}

En este escenario llegó la elección de septiembre de 1970 y el ascenso al poder de la Unidad Popular, representada por su candidato, Salvador Allende, en virtud de la suscripción del que se denominó "Estatuto de garantías", condición para que la Democracia Cristiana le diera sus votos en el Congreso Pleno.

No está de más recordar que fueron materia de dicho estatuto, entre otras, la mantención de la libertad de prensa, asociación y de opinión; la conservación de los tres poderes del Estado, y la división de atribuciones entre ellos; lo que refleja "que la Democracia Cristiana suponía o simulaba creer que la Unidad Popular pensaba instaurar algún tipo de dictadura"31.

Parte del programa de gobierno de la Unidad Popular consideraba la instauración de tres áreas de la economía, en razón de la propiedad de las empresas productoras de bienes o servicios: social, perteneciente al Estado; mixta, compartida con los particulares; y privada, de dominio de los privados. "El gobierno de Allende tarda en enviar al Congreso una ley que delimite estas áreas y mientras tanto se efectúan a diario requisiciones de empresas que pasan al área social mediante simples decretos del Ejecutivo"32.

En relación al programa político del nuevo gobierno, éste se proponía reemplazar el sistema bicameral del Congreso Nacional, por una cámara única, denominada Asamblea del Pueblo, cuyos miembros serían elegidos por sufragio universal, pudiendo ser revocado dicho mandato por la ciudadanía ${ }^{33}$.

${ }^{29}$ Boeninger, Edgardo, Democracia en Chile. Lecciones para la gobernabilidad (2 ${ }^{\mathrm{a}}$ edición, Santiago, Editorial Andrés Bello, 1997), pp. 148-149.

${ }^{30}$ Correa, Sofía, cit. (n. 16), p. 255.

${ }^{31}$ Moulian, Tomás, cit. (n. 27), p. 223.

${ }^{32}$ Fontaine Aldunate, Arturo, Todos querian la Revolución. Chile 1964-1973 (Santiago, Empresa Zig-Zag S.A., 1999) p. 119.

${ }^{33}$ Unidad Popular, Programa de la Unidad Popular (Santiago, 1969) Disponible en http://www.salvador-allende.cl/Unidad_Popular/Programa\%20de\%20la\%20 UP.pdf, p.7 
Esta Asamblea del Pueblo, a su vez, designaría a los integrantes de un Tribunal Supremo, sin otra limitación que la que emanare de la natural idoneidad de sus miembros. Este tribunal generaría libremente los poderes internos, unipersonales o colegiados, del sistema judicial ${ }^{34}$.

El objetivo perseguido por la Unidad Popular y expresado en este programa, era obtener que la nueva organización y administración de justicia fuera en auxilio de las clases mayoritarias de modo expedito y menos onerosa. Detrás de esta propuesta estaba la concepción de una nueva magistratura que reemplazaría la vigente, individualista y burguesa ${ }^{35}$.

Después de un año de iniciado el gobierno de la Unidad Popular, el Estado ya controlaba 62 industrias y administraba 39 empresas requisadas. La estrategia seguida por el Ejecutivo, y apoyada por los partidos de izquierda, agravó el conflicto con la oposición, a la que se sumaba el partido democratacristiano, quienes sostenían que la legalidad del país había sido transgredida. "En efecto, muchas de estas expropiaciones fueron objetadas por los tribunales, dando inicio a un complicado conflicto entre los poderes Ejecutivo y Judicial, pues tanto los trabajadores como los militantes de la Unidad Popular siguieron presionando por la intervención, aumentando por consiguiente los niveles de confrontación social y política, dejando en evidencia la incapacidad del gobierno para controlar sus bases" 36 .

En agosto de 1973 se habían expropiado, durante el gobierno de Allende, un total de 4.401 predios, a las que se sumaron las "tomas de fundos y de casas patronales, acciones incentivadas y amparadas, fundamentalmente, por grupos de los sectores más radicalizados de la Unidad Popular y por los miembros del MIR"37.

$\mathrm{Al}$ mismo tiempo que el Gobierno avanzaba en estas medidas, se fue acentuando progresivamente la violencia política en el país, con un carácter sistemático, obedeciendo a una doctrina violentista, por lo que no debía sorprender "que en 1971 aparecieran las primeras manifestaciones de una oposición asimismo dispuesta a ejercer la fuerza" ${ }^{38}$.

En su etapa final, Allende debió enfrentar el conflicto entre las dos líneas de pensamiento al interior de la coalición gobernante respecto al modo de implementar el programa revolucionario. De un lado, aquellos que defendían el particular proceso chileno, en virtud del cual se "hacía posible (como apuesta) la utilización del poder adquirido para acumular fuerzas, mediante

\footnotetext{
${ }^{34}$ Unidad Popular, cit. (n. 33), p. 8.

${ }^{35}$ Unidad Popular, cit. (n. 33), pp 8-9.

${ }^{36}$ Correa, Sofía, cit. (n. 16), p. 266.

${ }^{37}$ Correa, Sofía, cit. (n. 16), p. 267.

${ }^{38}$ Vial Correa, Gonzalo, Salvador Allende: El Fracaso de una Ilusión (Santiago, Centro de Estudios Bicentenario, 2005), pp. 92-93.
} 
la realización de un programa que pretendía combinar medidas democráti-

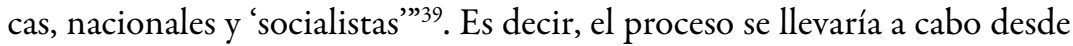
dentro del sistema político de democracia representativa liberal, mediante la formación de un "bloque por los cambios", que incluyera a la Democracia Cristiana, hasta alcanzar el "gobierno popular", puesto que no veían "posible una estrategia de grandes reformas llevada adelante por una minoría” ${ }^{\circ}$.

Por ello Mario Góngora afirma que tanto Allende como sus partidarios consideraban que el Estado burgués chileno les había permitido llegar al poder, razón por la cual debían aprovecharlo exhaustivamente para su transformación en socialista valiéndose hasta de los últimos resquicios legales ${ }^{41}$.

En el otro extremo, estaban aquellos que promovían la idea de superar el gradualismo y avanzar en el "desarrollo inmediato del 'poder popular', alternativo al Estado" ${ }^{42}$. No abandonaron la tesis de la dictadura del proletariado como fase previa y necesaria del proyecto revolucionario, promoviendo, incluso, la vía armada como opción inevitable ${ }^{43}$.

En el empeño por llevar adelante la "vía chilena", por imponer la "dictadura del proletariado", la Unidad Popular "había terminado por dañar gravemente el Estado de Derecho; había alineado en contra del Gobierno a gran parte del campesinado, de la clase obrera y de la pequeña y mediana burguesía; y, había terminado, también, por destruir el funcionamiento del aparato económico" 4 .

Bravo Lira sostiene, en síntesis, que el período 1964-1973 se caracterizó por la presión que los partidos políticos ideológicos, desde el gobierno, y con los medios de acción del presidente, ejercieron en contra de las instituciones establecidas, con un menosprecio de la legalidad vigente, intentando imponer desde arriba, su propia ideología $a^{45}$.

\section{Los cambios y la legalidad vigente.}

a) Preparando el camino. Tanto la denominada "Revolución en Libertad" promovida por el presidente Frei Montalva, como la "Vía Chilena

${ }^{39}$ Moulian, Tomás, cit. (n. 27), p. 241.

${ }^{40}$ Ibíd., p. 242.

${ }^{41}$ Góngora, Mario, cit. (n. 18), p. 290.

${ }^{42}$ Moulian, Tomás, cit. (n. 27), p. 243.

${ }^{43}$ Boeninger, Edgardo, cit. (n. 29), pp. 156, 158 y 159.

${ }^{44}$ Arriagada Herrera, Genaro, De la "Via Chilena" a la "Vía Insurreccional" (2a edición, Santiago, Editorial del Pacífico, 1974), p. 326.

${ }^{45}$ Bravo Lira, Bernardino, La crisis de la idea de Estado en Chile, durante el siglo $X X$, en Góngora, Mario (autor) Ensayo Histórico sobre la Noción de Estado en Chile en los siglos XIX y XX (7ª edición, Santiago, 1984), anexo 3, p. 397 y 402. 
al Socialismo" del presidente Allende, buscaban el desarrollo de cambios profundos para Chile, en principio, a través de los cauces institucionales.

El intento de implementar tales reformas entre 1964 y 1973, fue generando una creciente tensión en el ordenamiento vigente, en tanto ellas abarcaban áreas determinantes de la realidad nacional, y debían, además, acordarse con los partidos de oposición al Gobierno, y, en su caso, con grupos dentro de la misma coalición gobernante, partidarios de cambios más radicales y veloces.

La imposibilidad de satisfacer las expectativas generadas por la no obtención de los resultados de cambios esperados, fueron produciendo la necesidad de buscar vías alternativas que permitieran avanzar en los programas de gobierno propuestos, lo que determinó comportamientos "extralegales" o fuera del ordenamiento jurídico.

La vía institucional "no fue suficientemente expedita para realizar el proyecto de cambios de valores y estructuras propuestos por el presidente Frei y el Partido Demócrata Cristiano" 46 ; y, no obstante su conducción del proceso político, "durante su gobierno surgen y se acrecientan comportamientos colectivos extralegales [...] [como] las huelgas ilegales, tomas de Escuelas, tomas de sitios y tomas de caminos" ${ }^{\prime 7}$.

Para algunos, el período de Frei marcó el inicio de una larga etapa de conflicto político, económico y social, caracterizado por la "radicalización de sectores de izquierda, que habían públicamente desahuciado la vía institucional democrática y optado por la lucha armada para el cambio social" ${ }^{38}$; y por un aparente cuestionamiento del orden político democrático de parte de la derecha, pues ésta desconfiaba de "su capacidad de defender el orden económico-social vigente" 49 .

"En nuestra opinión, los partidos políticos y sectores de ultra izquierda y ultra derecha, en este período impactan directamente la institucionalidad. Las tomas y 'expropiaciones' inician la vía rupturista, porque atentan en contra de los valores centrales consagrados en la Constitución Política de 1925: el orden público interior y la propiedad" ${ }^{50}$.

Sin embargo, debe tenerse presente que Frei intentó llevar a cabo, en un período presidencial de seis años, una reforma estructural que abarcaba la concentración del poder político, mediante reformas constitucionales que

${ }^{46}$ Cumplido, Francisco - Balbontín, Ignacio, Proyecto de cambio e institucionalidad jurídico-politica. Chile 1964-1973, en Documento de Trabajo FLACSO, 72/78 (Santiago, 1978), p. 28.

${ }^{47}$ Ibíd., p. 28.

${ }^{48}$ Ibíd., p. 30.

${ }^{49}$ Boeninger, Edgardo, cit. (n. 29), p. 149.

${ }^{50}$ Cumplido, Francisco - Balbontín, Ignacio, cit. (n. 46), p. 31. 
otorgaran más facultades al Ejecutivo; del poder económico, a través de la reforma agraria, del desarrollo económico estatal, y del control de la gran minería del cobre; y del poder social, por intermedio de la denominada promoción popular como forma de organización. "Se imponía la necesidad de una revolución, de introducir cambios radicales en Chile, para lo cual era clave reforzar los poderes del Ejecutivo y dotarlo de adecuadas herramientas de planificación que le permitieran llevar a la realidad la ideología en todos los ámbitos de la sociedad, acrecentando al mismo tiempo la participación popular" ${ }^{21}$.

Cumplido y Balbontín sostuvieron como hipótesis de investigación sobre este período, que "el sistema jurídico-normativo chileno, en lo que respecta a legitimidad, complejidad y consistencia, constituía un sistema democrático formal; que el sistema de gobierno en Chile no permitía procesar cambios profundos de valores y estructuras de modo eficaz como para absorber demandas de ese tipo en el corto plazo; que los proyectos de cambio requerían una altísima capacidad de presión y un alto consenso para ser procesados por el sistema jurídico normativo chileno en el corto plazo; y que la acumulación de proyectos específicos rechazados o demorados por el sistema jurídico político, representativos de proyectos favorables al cambio, fueran concomitantes con el acrecentamiento de comportamientos extralegales" 52 .

b) El Derecho burgués. El período 1970-1973 estuvo marcado por la promoción decidida de reemplazo de las estructuras económicas "por otra que termine con el capital monopolista nacional y extranjero y con el latifundio, a fin de "iniciar la construcción del socialismo"'53.

Sin embargo, es sabido que Allende no contaba con la mayoría en el Congreso que le permitiera llevar a cabo su programa de gobierno, ocurriendo en la práctica un verdadero bloqueo entre estos poderes del Estado. Así, " $n i$ el presidente Allende podia imponer su criterio al Congreso para obligar a éste a proporcionarle la legislación apta para introducir y consolidar los cambios que él perseguia, ni el Congreso Nacional, dentro del cual tenian mayoria los opositores de Allende, podia imponer el suyo a éste para restarle al Ejecutivo las atribuciones con que contaba entonces, en cuanto fueren apropiadas para lograr esos cambios" 54 .

Lo anterior explica que Allende presionara duramente al Congreso, haciéndolo, incluso, responsable de eventuales excesos. "Nuestro sistema

${ }^{51}$ Brahm, Enrique - Bertelsen, Raúl - Amunátegui, Andrés, Régimen de Gobierno en Chile. ¿Presidencialismo o Parlamentarismo? 1925-1973 (Santiago, Editorial Jurídica de Chile, 2002) p. 171.

${ }^{52}$ Cumplido, Francisco - Balbontín, Ignacio, cit. (n. 46), pp. 5-6.

${ }^{53}$ NovoA, Eduardo, cit. (n. 8), p. 42.

${ }^{54}$ Ibíd., p. 47. 
legal debe ser modificado. De ahi la gran responsabilidad de las Cámaras en la hora presente: contribuir a la transformación de nuestro sistema jurídico. Del realismo del Congreso depende, en gran medida, que al legalismo capitalista suceda la legalidad socialista conforme a las transformaciones socio-económicas que estamos implementando, sin que una fractura violenta de la juridicidad abra las puertas a arbitrariedades y excesos que, responsablemente, queremos evitar"s5.

Pero quien tuvo a su cargo la estrategia para sortear los obstáculos que el sistema institucional ofrecía a los afanes reformistas del Ejecutivo, fue Eduardo Novoa Monreal, presidente del Consejo de Defensa del Estado entre 1970 y 1973, y asesor jurídico del presidente Salvador Allende.

Novoa sostenía que el ordenamiento jurídico imperante no era sino un mecanismo de defensa de la clase dominante para perpetuarse en sus privilegios. "Es el derecho burgués el que elevó a la categoría de axiomas jurídicos a algunas tesis que no son sino fruto de la intención de afirmar indefinidamente en elpoder al régimen politico, social y económico del liberal individualismo" 56 . Tales serían los conceptos de "derechos adquiridos", "seguridad jurídica", "respeto de lo pactado", entre otros, cuya defensa tendría por único objeto "que jamás puedan variarse las condiciones sociales o económicas, por injustas que sean, so pena de incurrir en el anatema de la 'juridicidad', del abandono del 'Estado de Derecho'o de paso a la 'ilegitimidad"'57.

La falta de apoyo que Allende hubo de enfrentar en el Poder Legislativo para efectuar las reformas constitucionales y legales que formaban parte de su programa de gobierno, llevaron a Novoa a indagar en la frondosa legislación chilena. Allí le fue "posible hallar los instrumentos legales capaces de romper la inercia del estancamiento fatal"s8.

A este conjunto de disposiciones legales, pertenecientes a épocas pretéritas de la historia legislativa chilena, se les denominó "resquicios legales". Se trataba, en algunos casos, de disposiciones legales olvidadas dictadas por regímenes que habían intentado cambiar las estructuras económico-sociales del país; en otros, se otorgaban facultades amplias, discrecionales y no regladas al Ejecutivo; y algunas que reconocían al Estado total libertad para actuar en la vida económica ${ }^{59}$.

${ }^{55}$ Allende Gossens, Salvador, Mensaje Presidencial de S.E. el Presidente de la República al Congreso Pleno, en Diario de Sesiones del Congreso Pleno, Legislatura $313^{a}$ Ordinaria Sesión del Congreso Pleno del 21 de mayo de 1971 (Santiago, 1971), p. 11.

${ }^{56}$ NovoA, Eduardo, cit. (n. 4), p. 11.

${ }^{57}$ Ibíd., p. 12.

${ }^{58}$ Ibíd., p. 20.

${ }^{59}$ Novoa Monreal, Eduardo, Vias legales para avanzar hacia el Socialismo, en Revista de Derecho Económico, 33-34 (Santiago, 1971), p. 28. 
A través de la aplicación de esta legislación, Allende logró dar un "marco inicial apropiado para desarrollar el área social de la economía y le permitió poner en marcha las primeras medidas para el cumplimiento de su programa" 60 . Así, se iniciaron la requisición de empresas, incluidas la facultad del Estado de incautar sus equipos e instalaciones; la intervención laboral y administrativa de empresas; y el desarrollo por parte del Estado de toda y cualquier actividad económica, que incluyó la apertura de poder comprador de acciones para adquirir por esta vía la propiedad de los bancos comerciales ${ }^{61}$.

De entre todas estas normas legales, la más representativa fue el Decretoley $\mathrm{N}^{\circ} 520$ promulgado por el Gobierno de Carlos Dávila en 1932; pues de ella se utilizó la herramienta de la expropiación de predios agrícolas y, sobre todo, de empresas industriales y de comercio, dedicados a la producción y distribución de artículos de primera necesidad ${ }^{62}$.

Esta legislación, a la que se sumaron el artículo 626 del Código del Trabajo que permitió al Gobierno ordenar la reanudación obligatoria de faenas en caso de huelga o cierre de fábricas o empresas; el artículo 171 de la Ley $\mathrm{N}^{\circ} 16.640$ de 1967 que establecía la designación de interventor en caso de paralización ilegal de labores, entre otras, "se pasaría a aplicar ahora en forma radical para alcanzar el objetivo socializador"63.

El escenario de la discusión política y la negociación de la agenda legislativa dejó de ser el Congreso, para concentrarse en el orden legal y jurídico. Mediante la aplicación de los "resquicios legales", el Ejecutivo prescindió del Poder Legislativo, y se valió de los mismos como instrumento directo de ejecución de su programa de gobierno. "Como se ha visto, la lucha irreconciliable que se sostiene entre la Unidad Popular y la derecha opositora, se centra principalmente en el plano legal en estos momentos $y$, verosimilmente, atendida las circunstancias y antecedentes, persistirá alli" ${ }^{\prime \prime}$.

A partir de este momento, la más frecuente acusación en contra de Allende dirá relación con su transgresión a la legalidad. Y es que para el entorno del gobernante, el sistema legal no podía ser mirado sólo como un conjunto de normas en vigor. Ello constituía el ordenamiento jurídico formal, al que había que incorporar un contenido, que estaba dado por la "expresión de una determinada concepción del hombre, de la sociedad y del mundo, en general, en un cierto momento histórico"65.

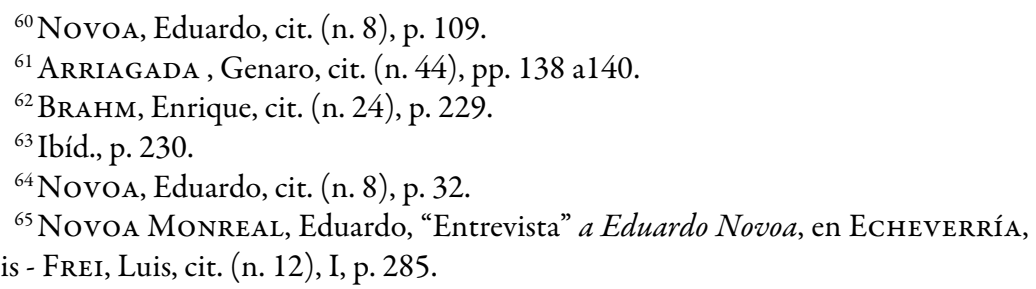


Se distinguía, entonces, entre el contenido de una norma, que dependería de elementos no jurídicos sino sociológicos; y la forma, condicionada por aspectos eminentemente jurídicos. Esta interpretación permitía al Gobierno sostener que, en lo formal, respetaba el Estado de Derecho y las normas legales que lo estructuran, pero, "simultáneamente, les da el contenido que corresponde a la definición de clase de las fuerzas sociales que están detrás del Gobierno"66, lo que en la práctica le permitía ejecutar ciertas normas con una finalidad distinta de aquella para la cual se habían concebido, generando el conflicto de interpretación con la oposición.

Bravo Lira sostiene que a la denominada legalidad formal, le siguió la legalidad sobrepasada, la que terminó siendo reducida a mero ritualismo. "Los gobernantes podían hacer lo que quisieran, con tal que procedieran por vías legales" ${ }^{67}$.

\section{LA INTERVENCIÓN DEL PODER JUDICIAL}

\section{La acusación constitucional contra la Corte Suprema.}

Según Bernardino Bravo Lira es un hecho cierto que la Judicatura "ha permanecido al margen de las crisis y conmociones hasta ahora inevitables dentro del estado constitucional, cada vez que la relación presidente-parlamento llega a un punto álgido" ${ }^{68}$, lo que ha representado una garantía de estabilidad para el ordenamiento jurídico.

Pero el período del gobierno de la Unidad Popular, en esto, fue la excepción. "La Corte Suprema no podía permanecer indiferente ante el nuevo giro de las cosas. La formación de un gigantesco aparato estatal y paraestatal a las órdenes del presidente de la República, la decadencia del parlamento y de los partidos y el surgimiento de nuevas organizaciones intermedias desde operarios hasta empresarios, las grandes planificaciones globales y el fin del régimen de gobierno, reemplazado por una serie de gobernantes que no se atienen a un marco fijo para ejercer el mando, sobrepasaron en todo sentido la Constitución y la leyes" ${ }^{\circ 9}$.

Sin embargo, no debe pensarse que el Poder Judicial inició una activa cruzada de protección y preservación del Estado de Derecho. Fiel a su tra-

${ }^{66}$ GARCÉs, Joan, Vía insurreccional y vía politica: dos tácticas, en Revista de la Universidad Técnica del Estado, 13-14 (Santiago, 1973), p. 13.

${ }^{67}$ Bravo Lira, Bernardino, El juez entre el Derecho y la ley, en el mundo hispánico (Santiago, LexisNexis, 2006), p. 638.

${ }^{68}$ Bravo LiRa, Bernardino, Los estudios sobre la judicatura Chilena de los siglos XIX y XX, en Revista de Derecho y Jurisprudencia, 51-52 (Santiago, 1992), pp. 106112.

${ }^{69}$ Bravo, Bernardino, cit. (n. 67), p. 640. 
dición, se trató más bien de una reacción al sentirse atacados por el Poder Ejecutivo, y ver su independencia amenazada.

Ya en 1969, al inaugurar el año judicial, el presidente de la Corte Suprema se refería al Estado de Derecho y a la separación e independencia de los Poderes del Estado como su estructura básica, y advertía que el "Derecho, mediante estos cuatro valores (libertad, igualdad, solidaridad y justicia) pasa a ser en la vida de las naciones, el motor impulsor que mueve a los individuos a buscar, sin temor, sus propios destinos. Pero, para llegar a este desideratum, es menester que cada uno de los tres Poderes referidos, cumpla debidamente con sus correspondientes atribuciones en cuanto a la vigencia del sistema juridico" ${ }^{\prime \prime}$. Y más adelante, recordaba como misión del Ejecutivo la de hacer "respetar el derecho e impedir el desorden, que es su antitesis, y dar oportuno cumplimiento a las sentencias emanadas del Poder Judicial"71.

La referencia a la independencia del Poder Judicial no era casual. A partir de esta fecha, será una constante de los presidente $s$ del máximo tribunal exigir para este poder del Estado el debido respeto de su autonomía.

A nuestro juicio, en este sentido marca un hito la acusación constitucional presentada por el Partido Socialista en 1967 en contra de la Corte Suprema, por haber ésta resuelto desaforar al senador de dicho partido, señor Carlos Altamirano.

a) La polémica conferencia. Al regreso de su visita a Cuba en 1967 , el senador Altamirano dictó una conferencia a los estudiantes de la Universidad de Concepción, en la que abordó distintos temas políticos, publicada más tarde en la revista Punto Final.

En ella, Altamirano efectuaba un paralelo entre la política chilena y la cubana, destacando que hoy la discusión debía cambiar desde las realidades locales al mundo latinoamericano, en cuyo escenario no tenían cabida lo antiguos actores de la política. "Los Haya de la Torre, los Betancourt, los Figueres, los Frondizzi y los Frei, todos ellos y a no tienen vigencia en el proceso histórico desatado por Cuba. Los unos por ineptos e incapaces, los otros por traidores y vendidos al status imperialista"72.

Las alianzas políticas y pactos electorales -aseguraba Altamirano- debían dar paso a los frentes guerrilleros; la lucha electoral, a la lucha armada revolucionaria a escala continental; el político tradicional que aspira a mantener

${ }^{70}$ Illanes Benítez, Osvaldo, Memoria leida por el Presidente de la Excma. Corte Suprema en la Sesión Inaugural del año 1969, en Revista de Derecho, Jurisprudencia y Ciencias Sociales y Gaceta de los Tribunales, 66 (Santiago, 1969) 1, p. vi.

${ }^{71}$ Ibíd., p. vi.

${ }^{72}$ Altamirano Orrego, Carlos, La lucha armada en América Latina, en Punto Final, Suplemento 31 (Santiago, 1967), p. 2. 
las garantías individuales dentro de farsas democráticas, al político guerrillero formado en la sierra o en la montaña ${ }^{73}$.

Tales cambios pasaban por la lucha que Cuba estaba dando por liberarse del imperialismo norteamericano, razón por la cual el senador socialista criticaba duramente al gobierno de Frei Montalva, quien a su juicio apoyaba "esta monstruosa conspiración reaccionaria, militarista, de yanquisy gobiernos titeres, para aplastar movimientos populares, revolucionarios latinoamericanos" ${ }^{74}$.

En este contexto, resaltaba la figura de Fidel Castro, a quien Altamirano calificaba como el símbolo vivo y dinámico de una revolución proletaria y marxista, en la que la libertad de los pueblos de América Latina sería fruto de su propia lucha; producto de los grandes combates armados librados por estas naciones ${ }^{75}$.

En la misma conferencia, el senador sostenía que el Partido Socialista apoyaba la concepción general de la estrategia cubana para enfrentar al imperialismo. "Más tarde o más temprano, la gran confrontación entre el imperialismo norteamericano y el proceso emancipador latinoamericano se darán en un plano armado; y para esa ocasión, debemos estar preparados" ${ }^{76}$.

Por lo tanto, la conclusión a la que Altamirano llegaba, era que el retraso y la miseria continental no podrán ser superados a través de las estructuras semicapitalistas, feudales, democráticas y burguesas imperantes, "como tampoco podrán serlo a través de los lentos procesos reformistas, vacilantes, indecisos y confusos" 77 .

b) El desafuero y condena final. Tras la publicación de la mencionada conferencia, dos fueron las acusaciones presentadas contra el senador socialista. La primera, la formuló el ministro de Defensa Nacional, quien denunció la infracción al artículo 131 del Código de Justicia Militar, al considerar ofensiva para las Fuerzas Armadas las afirmaciones efectuadas por Altamirano, cuyas expresiones serían constitutivas del delito contemplado en el artículo 284 del mismo Código.

En los primeros párrafos de la polémica conferencia, el senador sostuvo que "América Latina, gran nación deshecha en veinte repúblicas, tiene una superficie de 21.000.000 de kilómetros cuadradosy 240.000.000 de habitantes. El orden burgués y la explotación imperialista están cautelados por 1.200 .000 guardias nativos de ejércitos profesionales al servicio del Pentágono"; y más adelante agregaba: "Cómo derrotar a los ejércitos profesionales nativos y a sus tutores armados yanquis, guardianes del sistema de vida capitalista en esta

\footnotetext{
${ }^{73}$ Ibíd., p. 2.

${ }^{74}$ Ibíd., p. 3.

${ }^{75}$ Ibíd., pp. 4-5.

${ }^{76}$ Ibíd., p. 10.

${ }^{77}$ Ibíd.
} 
zona del hemisferio, es el gran dilema planteado a las vanguardias politicas continentales" 78 .

El pleno de la Corte de Apelaciones de Santiago, en fallo de 19 de agosto de 1967, consideró que las expresiones manifestadas por el senador en el texto de la conferencia, "importan una crítica al Gobierno respecto de su politica general en relación con las Fuerzas Armadas de la Nación, cuya dirección superior le compete exclusivamente en forma indiscutida, y siendo asi, no resulta atendible considerar que los conceptos del inculpado hayan sido dirigidos contra el Ejército, la Armada o la Aviación, por lo cual los términos que emplea el senador no alcanza a configurar la infracción punible que se contempla en el artículo 284 del Código de Justicia Militar"

Este fallo se acordó con el voto en contra de los ministros señores Aburto, Iturra, Pica y Raveau, quienes fueron de la opinión de declarar que procedía la formación de causa en contra del senador Altamirano, pues sus expresiones habrían importado "una ofensa para las Instituciones, ya que de los textos referidos se desprende que se imputa al Ejército de Chile ser mantenedor de un sistema politico-económico determinado, bajo la inspiración de una potencia extranjera y de sus organismos militares, desentendiéndose de la misión que las leyes de la República le encomiendan" $"$.

Por último, el ministro señor Galecio concurrió al fallo de mayoría, teniendo en consideración que, a su juicio, las expresiones del senador acusado corresponden a "opiniones politicas de carácter general, las que, atendido el contexto de la publicación, no cabe estimar dirigidas especialmente a injuriar al Ejército chileno, sino a formular un reproche a los órganos públicos de los cuales dependen en América Latina las decisionespoliticas, a las que el Ejército chileno, como organismo no deliberante, es totalmente ajeno"81.

Apelado este fallo para ante la Corte Suprema, ésta dictó sentencia con fecha 14 de septiembre de 1967, revocándolo y declarando, en su lugar, ha lugar a la formación de causa en contra del senador Carlos Altamirano Orrego.

Entre sus fundamentos, la Corte Suprema efectuó una interpretación literal de las afirmaciones vertidas por el senador socialista, concluyendo que "las referencias a los 'ejércitos nativos de América Latina al servicio del Pentágono y sus tutores armados yanquis' hechas por el senador inculpado en su aludido artículo de la revista 'Punto Final', comprende obviamente al Ejército de Chile, el que, por tanto, es, a sujuicio, un ejército de nativos al servicio

${ }^{78}$ Ibíd., p. 2.

${ }^{79}$ Corte de Apelaciones de Santiago, 19 de agosto de 1967, en Revista de Derecho y Jurisprudencia, 64 (Santiago, 1967) 7, $2^{\text {a }}$ parte, sección 4a , p. 279.

${ }^{80}$ Ibíd., p. 279.

${ }^{81}$ Ibíd., p. 280. 
del Pentágono y está bajo la tutoría armada yanqui"\$2; razón por la cual es posible concluir, en opinión del máximo Tribunal, que "al estar el Ejército de Chile al servicio de una dirección militar extranjera, como es el Pentágono, y sometido a la tutoría o protección armada 'yanqui, significa que su actuación estaria dirigida desde el extranjero y sus decisiones inhibidas u orientadas por autoridades extrañas a las nacionales" 83 .

Lo anterior, llevó a la mayoría de los miembros de la Corte Suprema, a excepción del ministro señor Ortiz, a declarar que "la expresión de tales ideas traspasa los limites de la critica politica, ofende el honor del Ejército y se introduce en el tema militar, ya que lo son [sic] los problemas del mando y sujeción en la jerarquia de las Fuerzas Armadas; y si, como sucede en el caso presente, se atribuye a las nuestras, entre las de América Latina, la subordinación a un mando extranjero, se incurre en apreciaciones que tienen los caracteres de delito previsto en el artículo 284 del Código de Justicia Militar, consistentes en injuriar u ofender de palabra o por escrito a las instituciones Armadas" 4 .

Como se ve hasta aquí, la apreciación que los altos magistrados han debido hacer de las afirmaciones vertidas por el senador socialista, en relación a la comisión de un eventual delito, corresponden más bien a la personal calificación o significado que a ellas les atribuyen. Es decir, mientras para algunos, éstas debían entenderse dentro de un contexto de crítica general de carácter político, y por tanto, no movidas por un animo de injuriar; para los otros, más apegados a una interpretación literal de las palabras, las solas referencias al sometimiento de nuestras instituciones armadas a una potencia extranjera, constituían en si mismas, injurias no calificables como meros reproches políticos.

Hay, a nuestro juicio, una clara opción por calificar la gravedad y mérito político del contenido de las palabras del senador socialista, teniendo presente el contexto histórico en el que fueron pronunciadas, especialmente la reivindicación de la revolución en Cuba y la vía armada para obtener los cambios propuestos por un sector de la clase política dirigente.

Lo anterior, se ve confirmado por los razonamientos de la sentencia de la Corte de Apelaciones de Santiago, al conocer y fallar la segunda acusación de carácter penal seguida contra el desaforado senador, por los delitos de injuria en contra del presidente de la República, y delitos contra la seguridad interior del Estado, incoada a requerimiento, esta vez, del ministro del Interior don Bernardo Leighton.

La Corte, en la persona del ministro sumariante señor Abraham

${ }^{82}$ Corte Suprema, 14 de septiembre de 1967, en Revista de Derecho y Jurisprudencia, 64 (Santiago, 1967) 7, 2a parte, sección 4a , p. 281.

${ }^{83}$ Ibíd.

${ }^{84}$ IBÍD. 
Meershon, dio por acreditado el delito de injurias proferidas en contra del presidente de la República por el senador Altamirano, en el contexto de un párrafo de la conferencia dictada en la Universidad de Concepción, en la que afirmaba que: "Los Haya de la Torre, los Betancourt, los Figueres, los Frondizzi y los Frei, todos ellos ya no tienen vigencia en el proceso histórico desatado por Cuba. Los unos por ineptos e incapaces, los otros por traidores y vendidos al status imperialista" ${ }^{85}$.

La defensa sostenida por el senador apuntaba a que en tales afirmaciones debía distinguirse a los dos primeros mencionados, respecto a los cuales, para cualquier político latinoamericano, resultaba obvio la aplicación de los calificativos "traidores y vendidos al status imperialista"; en tanto que, para el resto de los nombrados sólo cabrían los epítetos de "ineptos e incapaces"

$\mathrm{Al}$ respecto, la Corte estableció en el considerando sexto que no podía pretenderse "que los estudiantes que oyeron su disertación en la Universidad de Concepción y los lectores que leyeron su artículo publicado en el suplemento de 'Punto Final' sean todos precisamentepoliticos latinoamericanos, de modo que, al menospara la generalidad de ellos, han quedado totalmente indiferenciados los epitetos en relación a los personajes tachados"

Que frente a la explicación de Altamirano respecto a que los primeros calificativos estaban dirigidos a los partidos políticos a los que pertenecían estos dirigentes en Venezuela y Perú; no así a Frei, la Corte de Apelaciones razona en su considerando séptimo que "no es posible confiar que mediante tan confuso circunloquio alguien pueda quedar debidamente informado de que esos dicterios estaban exclusivamente enderezados a los nombrados políticos, pues para llegar a esta conclusión habria sido menester que, en presencia del párrafo en cuestión, el oyente o lector se forjase el problema de desentrañar a quiénes se quiso motejar de 'ineptos e incapaces' y a quiénes de 'traidores y vendidos al status imperialista'. [...]. Y resulta tan arduo este razonamiento que ni el propio conferencista habria podido abrigar la idea de que alguien lo interpretase asi, es más, no ha intentado siquiera que se lo entendiera asi, porque de lo contrario habría disipado fácilmente la ambigüedad"88.

Como se ve, más que razones jurídicas, el ministro sumariante acudió a los usos y costumbres de la vida política con el fin de determinar la intencionalidad de las palabras del desaforado senador, y concluir así el carácter injurioso de las mismas.

Por ello, el mismo considerando séptimo remata afirmando que "sus

${ }^{85}$ Altamirano, Carlos, cit. (n. 72), p. 2.

${ }^{86}$ Corte de Apelaciones de Santiago, 15 de enero de 1968, en Revista de Derecho y Jurisprudencia, 65 (Santiago, 1968), 2a parte, sección 4a , p. 20.

${ }^{87}$ Ibíd., p. 20.

${ }^{88}$ Ibíd., p. 21. 
expresiones anfibológicas no pueden estimarse como un desafortunado desliz retórico, sino como una sutil fórmula de cubrir con todos sus epitetos a las personas nombradas" 89 .

En seguida, Altamirano sostuvo en su defensa que sus afirmaciones constituían una crítica política, según lo había asentado la jurisprudencia, en términos que "la critica, por acerba que sea, movida por actos politicos que son de dominio público, aún siendo injusta o exagerada, no puede constituir delito" por lo que no podía estimarse agraviante al jefe de Estado. Al respecto, el considerando décimo del fallo sostuvo que "no puede dejarse tampoco de reconocer que en el párrafo de que se trata no hay crítica alguna, en el recto sentido de la palabra, con respecto a los actos politicos del presidente de la República, sino, lisa y llanamente, hay un ocioso y gratuito vilipendio a su persona; $y$ no tiene validez que se invoque en este caso, como lo hace también la defensa, el derecho del politico de oposición para calificar la capacidad de los gobernantes para resolver los problemas de su pais, pues, sin refutar la licitud de ese derecho, lo cierto es que el senador Altamirano no ha calificado en esta oportunidad la capacidad o aptitud del presidente de la República en relación a su desempeño como gobernante de este pais, sino simplemente lo ha motejado para motivar por qué 'ya no tiene vigencia en el proceso histórico desatado por Cuba" ${ }^{\text {"90. }}$.

La Corte no deja de tener presente que la conferencia dictada por Altamirano se enmarca en el contexto de su reciente visita a Cuba, y en una descripción de la revolución que allí se ha llevado a cabo, comparándola con la realidad política nacional. Por ello, más que una simple crítica al desempeño del jefe de Estado, el Tribunal de Alzada entiende, con un claro sentido político, que tras estas afirmaciones está la intención de promover el modelo cubano como el camino a seguir; y en el que los actuales dirigentes aparecen más bien como un obstáculo.

Así también queda claro al revisarse el razonamiento de la Corte de Apelaciones de Santiago respecto de la imputación del delito contra la Ley de seguridad interior del Estado efectuada al senador socialista, y en la que hubo de determinar si existió apología de doctrinas, sistemas o métodos que propugnaran el crimen o violencia como medios para lograr cambios o reformas políticas, económicas o sociales ${ }^{91}$.

En efecto, frente a la descripción que Altamirano hace de la estrategia de lucha planteada por Cuba para liberar al continente de "la implacable explotación imperial, del hambre, del analfabetismo, del retraso, y del subdesarrollo", la Corte razona en su considerando diecinueve que éste "no se limita a

\footnotetext{
${ }^{89}$ Ibíd.

${ }^{90}$ Ibíd.

${ }^{91}$ Ley N 12.927 de Seguridad del Estado, artículo 6º letra d).
} 
explicar escuetamente en quéconsiste aquella estrategia, sino que también pone de contraste las concepciones y personajes que conciernen a Cuba con los que atañen a los de los demás países latinoamericanos y se esmera en amenguar tan marcadamente la actual ordenación de estos últimos paises que, por carambola, no sólo deja patentizada su propia afición por la estrategia que propugna Cuba, sino que resulta más animoso su encomio por dichos postulados" 92 .

Que después de un pormenorizado análisis de los dichos del desaforado senador, el ministro sumariante concluye que éste "se propuso a un tiempo divulgar la estrategia de luch a concebida por Cuba, señalar su apego a ese sistema, exaltar a sus secuaces y acuciar su aplicación. Más aún, ha procurado persuadir a sus oyentes y lectores a colaborar con ella", por lo que debe entenderse que el procesado incurrió en apología y propaganda"93.

En seguida, la Corte de Santiago dio por sentado en su considerando $24^{\circ}$, $25^{\circ}$ y $29^{\circ}$, que el senador Altamirano preconizaba un sistema o método, como era el Cubano, que propugnaba básicamente la violencia para la consecución de sus fines. "En suma, si el imperialismo y todo lo que a él está adscrito han de ser vencidos por la lucha guerrillera, fuerza es concluir que la consabida estrategia está planteada para lograr fundamentalmente cambios estructurales en el ámbito de toda América Latina y que su manera de operar importa, al menos en Chile, la subversión del sistema institucional de funcionamiento de nuestra democracia representativa"; y sentenciaba: "conviene, sin embargo, destacar una vez más el marcado carácter de instigación indirecta a la violencia que presenta el ensayo del susodicho parlamentario"94.

En virtud de este juicio, nos parece que el Poder Judicial asumió una clara opción de protección del orden institucional, el que consideró amenazado por las características de la expansión de la revolución cubana a los países latinoamericanos, entre ellos Chile, y que el senador socialista promoviera en la señalada conferencia.

c) La acusación constitucional y respuesta de la Corte Suprema. En octubre de 1967, diez diputados del Partido Socialista presentaron una acusación constitucional en contra de todos los miembros de la Corte Suprema, cuyo texto fue dado a conocer en el Senado, un día antes de su interposición, por el senador Aniceto Rodríguez.

En éste, se acusaba al máximo tribunal de notable abandono de deberes, así como de graves infracciones y atropellos de hecho y de derecho, con ocasión del fallo dictado en la causa de desafuero seguida en contra del senador Carlos Altamirano, que acabamos de revisar.

\footnotetext{
${ }^{92}$ Corte de Apelaciones de Santiago, cit. (n. 86), p. 24.

${ }^{93}$ Ibíd., p. 26.

${ }^{94}$ Ibíd., p. 26-30.
} 
En efecto, a juicio de los diputados socialistas, y haciendo suyas las palabras de Eduardo Novoa Monreal, la justicia actuaba al servicio de la clase dominante. "Por un lado los empresarios, los terratenientes, los monopolios, el gran capital nacionaly extranjero procuran acrecentar sus influenciasy cercenar los derechos de las masas. Por el otro, éstas combaten a los sectores privilegiados para arrancarles nuevas conquistas de mayorbienestar. Porun lado, los Poderes Públicos tratan de restringir al máximo las libertades populares y de recurrir a la violencia para defender a la minoría. Por el otro la clase trabajadora exige cada vez con mayor intransigencia el respeto y la ampliación de las libertades ya alcanzadas y se resiste al uso de la violencia reaccionaria"'

En este contexto, los diputados acusaban abiertamente a la Corte Suprema de intervenir de forma directa en la actividad política, confirmación de lo cual era el fallo que desaforaba al senador de sus filas. "Esta actuación eminentemente politica de la Corte Suprema se ha acentuado con el fallo que desaforó al senador Altamirano, pues ese Tribunal, ya no sólo procede como censor de la crítica política, sino que de las ideas que puede divulgar un parlamentario" ${ }^{\prime \prime}$.

Más aún, consideraban que la más alta magistratura se había aliado con el Gobierno para representar a las castas oligárquicas, en una ofensiva contra el movimiento popular. Así, declaraban que la "Corte Suprema se ha convertido en un lastre y en un escollo para el avance social, económico y político de nuestro pueblo, por su aplicación regresiva de la ley. Ahi están sus fallos cavernarios en materia de legislación laboral, de arrendamiento, en materia penal, agraria y tributaria, y sus sentencias en procesos por delito politico"97.

El desafuero del senador Altamirano representaba para los diputados Socialistas un retroceso en los cambios que se pretendían impulsar, del que la Corte Suprema era responsable; haciéndose "cómplice de la impermeabilidad que el orden legal chileno demuestra al cambio, a la transformación auténticamente revolucionarias que esta hora exige" 98 .

Se le reprochaba a la Corte, en definitiva, haberse inmiscuido en asuntos que son propios de la discusión y análisis público, como es la concepción marxista de la vida y de la historia, al punto de llegar a proscribirlas. "Considerar que el hecho de 'destacar, extender el conocimiento y alabar el sistema social y politico imperante en Cuba', constituye un delito, importa no sólo transformar esa figura en un delito de opinión, sino que, además, revela la pretensión

${ }^{95}$ Rodríguez Arenas, Aniceto, Acusación constitucional del Partido Socialista contra la Corte Suprema, en Diario de Sesiones del Senado, Sesión 12a, martes 24 de octubre de 1967 (Santiago, 1967), p. 411.

${ }^{96}$ Rodríguez, Aniceto, cit. (n. 95), p. 414.

${ }^{97}$ Ibíd., p. 413.

${ }^{98}$ Ibíd., p. 416. 
inquisitorial de proscribir de nuestra esfera cultural e intelectual, formas de pensamiento como lo es el marxista"

La respuesta de la Corte Suprema no se hizo esperar. Y aun cuando no se trata de un fallo judicial, resulta interesante de revisar, puesto que, sometida al juicio de los diputados, la Corte resolvió abordarla desde una óptica jurídica y también política.

Desde un punto de vista general, la Corte calificó la acusación como confusa, infundada y de finalidad puramente política; en tanto que respecto a los acusadores, les atribuyó ansias de desprestigio y utilización de las libertades públicas para procurar su destrucción ${ }^{100}$.

Según su criterio, la lucha de clases era un mito que los acusadores estaban interesados en crear más que en desenmascarar; no existía separación tajante entre la clase trabajadora, por una parte, y los empresarios, los terratenientes, los monopolios y el gran capital nacional y extranjero, por la otra; a juicio de la Corte Suprema, los poseedores de la riqueza repartían cada vez más sus utilidades entre los que concurren con ellos a la producción de los bienes, por lo que hablar de la lucha de masas para arrancar nuevas conquistas de los sectores privilegiados, era despertar rencores censurables y emplear palabras que no reflejaban la verdad ${ }^{101}$.

El máximo tribunal no titubeó en efectuar su propio examen de la realidad social, afirmando que en Chile las diferencias sociales habían desaparecido. "Hombres de modesto origen económico se han elevado por su inteligencia, por su honorabilidad, por su laboriosidad hasta las más encumbradas posiciones politicas y sociales, [...] y esto demuestra que no están en lo cierto los acusadores cuando dicen que las autoridades representan a los poseedores de la riqueza económica"102.

La Corte destinó también parte de su presentación a la defensa de la independencia del Poder Judicial, imputando a los acusadores que "son ellos los que han invadido con su acusación atribuciones del Poder Judicial pretendiendo incitar al Parlamento a que revise los fallos de la Judicatura. Pretenden asi destruir la base de nuestro régimen jurídico que consiste en la separación de los Poderes del Estado"103.

Por esta razón, no dudaron en acusar a los diputados patrocinantes de buscar el desprestigio del Poder Judicial, "sin meditar que con su actitud no-

${ }^{99}$ Ibíd., p. 443.

${ }^{100}$ Corte Suprema, Respuesta de la Excelentísima Corte Suprema a la acusación constitucional deducida por diez señores Diputados, en Diario de Sesiones de la Cámara de Diputados, Sesión 16a, martes 14 de noviembre de 1967 (Santiago, 1967), p. 1.504

${ }^{101}$ Corte Suprema, cit (n. 100), p.1506.

${ }^{102}$ Ibíd., p. 1506.

${ }^{103}$ Ibíd., p. 1504. 
toriamente reprochable, por lo falaz de sus cargos, están inflingiendo un rudo golpe a su propia Patria, en el sentido jurídico, politico y social" 104 .

Por último, y en relación a los argumentos esgrimidos para acoger el desafuero del senador Altamirano, y que motivó la acusación constitucional, la Corte Suprema defendió su proceder, deslegitimando el uso de la violencia como mecanismo de acción política, afirmando, de paso, su papel de garantes del Estado de Derecho. En efecto, declaró que la "democracia usó del camino constitucional y estableció un delito peligroso para contrarrestar la incitación a usar las armas con el objeto de cambiar el régimen jurídico vigente" 105.

Más aún, la cabeza del Poder Judicial emitió su juicio de valor respecto de la ideología revolucionaria que ciertos grupos promovían, al preguntarse: “ ¿la democracia debe ser un régimen inerme ante la propagación de otras ideas que propugnan su aniquilamiento?" ${ }^{106}$; para luego reprochar directamente a los acusadores si acaso " ¿sienten la nostalgia de la gloria armada que la estructura legal chilena les arrebata de las manos, prontas a que 'los de abajo' empleen la metralla para matar o morir por un ajeno y misterioso ideal?" 107.

La Corte planteaba que hasta ese momento habían sido los Poderes Públicos, mediante el uso de las herramientas legales vigentes, los que habían corregido las injusticias y evitado las arbitrariedades promovidas por aquellos sectores que "recurren a la violencia, o a los que la proclaman como único medio factible del 'cambio de estructura' que preconizan"108.

\section{El auxilio de la Fuerza Pública.}

La facultad de hacer ejecutar lo juzgado constituye una prerrogativa esencial del Poder Judicial, de modo que aquello que resuelven no sólo quede en el papel, sino que también se haga efectivo en la realidad. La facultad de imperio de los Tribunales de Justicia es ejercida por ellos con el auxilio de la Fuerza Pública, lo que asegura el cumplimiento de sus resoluciones.

Este aspecto tan sensible del ordenamiento jurídico, sin embargo, se fue progresivamente deteriorando en perjuicio del Poder Judicial, por la intervención de la autoridad política.

En efecto, siendo la Fuerza Pública dependiente de las Intendencias, los Tribunales de Justicia debían solicitar a ella su auxilio; lo que devino en la creciente práctica de la previa calificación política del mérito y oportunidad de tal ayuda en el cumplimiento de las resoluciones.

Ya en 1965, la Corte Suprema declaró inaplicable por inconstitucional

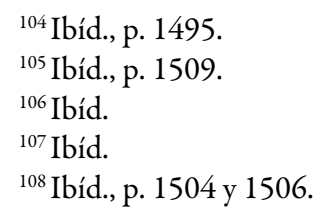


el artículo 91 de la Ley $\mathrm{N}^{\circ} 16.068$ en un juicio de arrendamiento. En efecto, el citado artículo disponía que durante el plazo de 6 meses, las autoridades administrativas no podrían conceder la fuerza pública para lanzamientos o desalojos de arrendatarios o subarrendatarios, que acreditaren estar al día en el pago de sus rentas de arrendamiento.

Es sabido que el procedimiento de lanzamiento es el camino necesario para ejecutar una sentencia, pronunciada en un juicio sobre terminación de contrato de arrendamiento por no pago de rentas. Por lo tanto, "al impedir el citado art. 91 de la Ley 16.068, que la autoridad administrativa conceda el uso de la fuerza pública para hacer ejecutar lo juzgado en el respetivo juicio, vulnera el art. 80 de la Constitución Politica del Estado, porque priva de imperio, por la vía administrativa, a las resoluciones judiciales contraviniendo y contrariando ese precepto, que como se manifestó, otorga en forma privativa y excluyente a los Tribunales de Justicia la facultad de juzgar las causas civiles $y$ criminales" 109.

Detrás de esta sentencia, hay un empeño de la Corte por mantener las prerrogativas que aseguraban una adecuada independencia del Poder Judicial. Incluso, podría decirse que, más allá de la defensa de los derechos del particular agraviado, la Corte estaba velando por un principio político institucional, como era el de separación de poderes.

Así, continúa razonando la Corte en su fallo: "Esta división de Poderes, o más bien, de acuerdo con el concepto moderno, separación o división de funciones, es el fundamento en que descansa la libertad y las garantias y derechos individuales, y ella no es absoluta, pero si de tal naturaleza que cada uno de los Poderes no interfiera ni suspenda las decisiones que son propias y privativas del otro" 110 .

Y concluía con el reproche a la autoridad política: "En consecuencia, el Poder Público en que la soberania ha delegado la función de administrar justicia tiene la facultad de hacer ejecutar lo juzgado, usando de la fuerza si ello es necesario, porque de otro modo su potestad e independencia no existirian, ya que otro u otros Poderes tendrian el control de sus actos, interferirian e impedirian el ejercicio de sus funciones, porque si una autoridad diferente estuviera autorizada para determinar si debe usarse o no la fuerza para hacer ejecutar lo juzgado, desaparecería la independencia del Poder Judicial, que unida a la inamovilidad de los jueces, es el fundamento esencial del resguardo $y$ del mantenimiento del orden jurídico de la Nación"111.

La negativa por parte de la autoridad ejecutiva a prestar el necesario

${ }^{109}$ Corte Suprema, 3 de mayo de 1965, en Fallos del Mes, año VII, 78 (Santiago,1965), p. 83.

${ }^{110}$ Corte Suprema, cit. (n. 109), p. 82.

${ }^{111}$ Ibíd., p. 83. 
auxilio de la fuerza pública para la ejecución de los fallos judiciales se vería profundizada y extendida durante el gobierno de la Unidad Popular.

En efecto, el Gobierno decidió privar de la facultad de imperio a los Tribunales de Justicia. "En adelante los jueces podrían dictar las sentencias que quisieran, pero sólo se concedería la fuerza pública para cumplir aquellas que el Gobierno determinara"112.

El 19 de enero de 1973, el ministro del Interior general Carlos Prats dictó una circular confidencial dirigida al general director de Carabineros, en la que instruía que toda orden emanada de Tribunal competente dirigida a dicha institución y que ordenara el desalojo de un determinado establecimiento o industria, debía ser informado por el jefe policial al Intendente o Gobernador respectivo. "Si las circunstancias laborales o de otra indole determinan que se trata de un caso conflictivo, que incida en los deberes que le señala el artículo 45 de la Ley de Régimen Interior, el Intendente o Gobernador comunicará por escrito al Ministerio del Interior y al jefe de Carabineros, que es indispensable suspender la ejecución del desalojo, a fin de deslindar responsabilidad de la fuerza pública". ${ }^{113}$

La falta de auxilio de la fuerza pública fue materia de denuncia reiterada por parte de los tribunales. Así lo hacía presente el pleno de la Corte Suprema en oficio dirigido al presidente de la República, al conocer de los hechos denunciados por el Juez del $8^{\circ}$ Juzgado del Crimen de Santiago, a quien el interventor designado por el Gobierno le impidió, con violencia, efectuar una inspección personal en los Establecimientos ALMAC en octubre de $1972^{114}$.

En efecto, el máximo tribunal representaba al Ejecutivo que a la sucesión de actos públicos en que se difamaba e injuriaba al Poder Judicial "ante la indolente tolerancia de la autoridad administrativa correspondiente"; se sumaba ahora el incumplimiento por parte de los jefes policiales de las resoluciones judiciales, al ser calificadas por éstos como inconvenientes atendido el estado de emergencia declarado, como fue el caso de la orden de devolución del diario La Mañana de Talca a su dueño. "Que la conducta de las autoridades, o de bisoños o anónimos oradores que en función oficial o en reiteradas concentraciones a lo largo del pais, han proferido epitetos soeces

${ }^{112}$ Arriagada, Genaro, cit. (n. 44), p. 251.

${ }^{113}$ Ministro Del Interior, Circular confidencial del Ministro del Interior sobre cumplimiento de órdenes judiciales, en ECHEvERRÍA, Luis - FreI, Luis, cit. (n. 12, III, p. 154.

${ }^{114}$ Corte Suprema, Necesidad de acatamiento de decisiones judiciales por autoridades administrativas. Representación a S.E. el Presidente de la República, en Libro de Actas de Acuerdos del Pleno de la Corte Suprema, 79 (Santiago, 30 de octubre de 1972), p. 264. 
en contra de la Magistratura, es un peligroso sintoma de la alienación contra la ley que se está apoderando de algunos espiritus ilegitimamente rebeldes. [...]. Que los hechos acaecidos y las transgresiones constitucionales y legales descritas pudieron ser, y no lo fueron, eficazmente impedidos por una orden oportuna de S.E. el presidente de la República. [...]. Representar a S.E. el presidente de la República la imperiosa necesidad de que se sirva instruir a sus Secretarios de Estado [...] acerca del estricto acatamiento de las decisiones que en el ejercicio de susfacultades constitucionales expidan los tribunales Ordinarios de Justicia $y$ acerca del trato cortés que sus funcionarios merecen, orden que sería remedio seguro a los males descritos"115.

En los meses venideros, serían materia de obligado análisis por el Pleno de la Corte Suprema, y consecuentemente de oficios dirigidos al Ejecutivo, los diferentes casos de incumplimiento de órdenes judiciales por falta de auxilio de la fuerza pública, que llevaron al Máximo Tribunal a declarar derechamente que los actos de la autoridad política ponían en riesgo el mantenimiento del orden jurídico, así como la estabilidad de los derechos y la conservación del orden público, lo que necesariamente conduciría a la crisis del estado de derecho, y a un perentorio e inminente quiebre de la juridicidad del país ${ }^{116}$.

\section{Expropiaciones.}

Tal como se dijo con anterioridad, el proceso de reforma agraria fue profundizándose a partir de la llegada del presidente Frei Montalva al Gobierno.

Ello trajo consigo modificaciones legales, y por tanto, el aumento de los conflictos judiciales derivados del progresivo incremento de las expropiaciones.

Una de esas modificaciones es la que contienen algunas disposiciones transitorias de la Ley $\mathrm{N}^{\circ} 16.640$ sobre reforma agraria, en relación con la Ley $\mathrm{N}^{\circ} 15.020$, respecto a las expropiaciones decretadas al amparo de ésta última, y en particular, a los procesos sobre reclamaciones ${ }^{117}$.

${ }^{115}$ Ibíd., pp. 266 a 268.

${ }^{116}$ Véase: Corte Suprema, Incumplimiento órdenes judiciales y negativa de la fuerza pública por Intendente de Santiago Sr. Faivovich, en Libro de Actas de Acuerdos del Pleno de la Corte Suprema, 18 (Santiago, 12 de abril de 1973), pp. 22 ss.; Incumplimiento órdenes judiciales, en Libro de Actas de Acuerdos del Pleno de la Corte Suprema, 21 (Santiago, 7 de mayo de 1973), p. 30 ss.; Incumplimiento órdenes judiciales, en Libro de Actas de Acuerdos del Pleno de la Corte Suprema, 22 (Santiago, 16 de mayo de 1973), pp. 33 y ss.; Incumplimiento órdenes judiciales. $2^{\circ} \mathrm{Jdo}$. L. Rancagua, en Libro de Actas de Acuerdos del Pleno de la Corte Suprema, 25 (Santiago, 25 de mayo de 1973), pp. 39 ss.

${ }^{117}$ Para más detalles del contenido de la Ley $\mathrm{N}^{\circ} 16.640$, véase: BRAHM, Enrique, cit. (n. 24), pp. 182 a 193. 
En el caso que analizaremos, se interpuso un recurso de inaplicabilidad de estas normas transitorias de la ley 16.640, en juicio seguido en contra de la Corporación de Reforma Agraria, ante el Tribunal de Expropiaciones Agrarias de Santiago, sobre reclamo de la procedencia de la expropiación y monto de las indemnizaciones, al amparo de las disposiciones de la Ley $\mathrm{N}^{\circ}$ 15.020 .

En efecto, se sostuvo por los recurrentes que las normas de la nueva ley de reforma agraria limitaban las facultad de los órganos jurisdiccionales, restringiéndolos a ratificar lo que ella disponía. Esto, constituiría una "violación flagrante al principio de la independencia del Poder Judicialy una burla a las prerrogativas de los Tribunales de Justicia"118.

Planteaban así, que era el legislador el que estaba obligando a los tribunales a fallar de una manera específica, pues la ley no le dejaba margen interpretativo distinto al texto expreso de la misma. Muchas de las reclamaciones que se tramitaban ante los tribunales tenían por objeto obtener una mejora de las indemnizaciones fijadas por la autoridad administrativa; y era justamente labor de la justicia el buscar los parámetros para su justa fijación. Sin embargo, la disposición transitoria de la Ley $\mathrm{N}^{\circ} 16.640$ estableció que todas aquellas indemnizaciones no perfeccionadas en cuanto a la determinación del monto, a la fecha de entrada en vigencia de la nueva ley, se regirían por las nuevas reglas, que fijaban tal indemnización en el avalúo vigente de la propiedad, haciéndolo extensivo también a los juicios pendientes de resolución.

Y si bien la Corte comenzaba la revisión de este recurso fijando con claridad hasta dónde se extendía la función jurisdiccional, la que incluía -a su juicio- "la misión de hacer la interpretación oficial de la ley, fijando el espiritu de la legislación, adaptándola a las necesidades sociales y extendiendo su poder regulador a los problemas que surgen con posterioridad a su dictación, con el objeto de reestablecer el equilibrio en los intereses de la sociedad, cuando estos han sido violentados y también prevenir dich a alteraciones" 119 ; sin embargo, luego, razonando con un especial realismo político, el voto de mayoría se inclinó por sostener que "no es fácil determinar con certeza absoluta cuál es la línea de separación que debe existir entre la función legislativa y la jurisdiccional en estas materias, en que preceptos de una ley entran a reglamentar situaciones nacidas al amparo de otra anterior, como ocurre en el presente caso" ${ }^{120}$. Más aún, el máximo Tribunal reconocía que en ciertas ocasiones era posible que los jueces se vieran "constreñidos de tal manera por los términos especificos de la ley que no pueden dejar de aplicar, y que en definitiva, sea ésta la que resulte

${ }^{118}$ Corte Suprema, 4 de enero de 1968, en Fallos del Mes, año IX, 110 (Santiago, 1968), p. 340.

${ }^{119}$ Ibíd., p. 342.

${ }^{120}$ Ibíd. 
resolviendo el conflicto concreto, como ocurre especificamente con las leyes interpretativas a que se refiere" 121 .

En este caso, la Corte opta por un legalismo estricto, con independencia de lo justo o injusto que resulte la aplicación de una norma al caso específico. Más aún, declara que debe hacer abstracción de todo efecto o consecuencia de la ley, aún de la injusticia o arbitrariedad que ella pueda implicar. Bajo el pretexto de una aplicación objetiva de la ley, la Corte Suprema terminó por declarar en este caso que "el recurso de inaplicabilidad es extraordinario, y por lo mismo, de estricto derecho y su finalidad no es otra que de resolver, en cada caso, si uno o varios preceptos legales son o no contrarios a la Constitución, finalidad que impide a este Tribunal, que es el llamado a conocer de él, pronunciarse acerca de la justicia o de las consecuencias que puedan producir las disposiciones de una ley, por duras e inconvenientes que parezcan, si ellas no contrarian las garantias que el Estatuto Fundamental asegura"122.

De especial significación en este fallo resulta el voto disidente, que estuvo por acoger la inaplicabilidad respecto de ciertos artículos de la Ley $\mathrm{N}^{\circ} 16.640$, pues los ministros señores Varas, Urrutia, Bórquez y Martín adscribieron justamente a la teoría política inversa al voto de mayoría. En efecto, y amparados en la discusión que esta ley generó en el Senado al momento de ser aprobada, consideraron que el artículo 80 de la Constitución Política, que consagra la independencia del Poder Judicial, debe "interpretarse en forma racional, y atender fundamentalmente a su finalidad de que los tribunales se encuentran en plena libertad de juzgar, resolver y de ejecutar las sentencias en los asuntos que le han sido sometido a su conocimiento" 123 ; de modo tal que si "el Parlamento a virtud de una ley obliga a un Tribunal de Justicia a dictar sentencia en determinado sentido, o bien, le impide ejecutar lo resuelto, dicho precepto legal quebranta la norma constitucional porque coloca a la Justicia en la imposibilidad de resolver en forma libre y eficaz la contienda que le habia sido sometida, interfiere en la independencia que debe existir entre los Poderes del Estado"124.

Especial reproche mereció a los ministros disidentes el contenido del artículo $3^{\circ}$ transitorio de la Ley $\mathrm{N}^{\circ} 16.640$, que facultaba a la autoridad administrativa a proceder con la expropiación de ciertos predios en el caso de haber procedido a tomar posesión material de ellos, aún habiéndose acogido las reclamaciones legales de sus propietarios en cuanto a la procedencia de la expropiación por los tribunales de justicia; "declaración cuya consecuencia

\footnotetext{
${ }^{121}$ Ibíd.

${ }^{122}$ Ibíd., p. 347.

${ }^{123}$ Corte Suprema, 4 de enero de 1968, en Revista de Derecho y Jurisprudencia, 65

(Santiago, 1968) 1, 2a parte, sección 1a , p. 30.

${ }^{124}$ Corte Suprema, cit. (n. 123), p. 30.
} 
inmediata es la imposibilidad en que deja al Tribunal respectivo para cumplir lo resuelto, lo que por lo demás es inaceptable en un régimen de derecho"125.

En este caso, el voto de minoría decidió hacer frente a una legislación cuyo claro objetivo era llevar adelante el proceso de expropiación, aún contra los pronunciamientos de los tribunales. Es decir, se dejaba a los propietarios en el más completo desamparo, puesto que no obstante haber obtenido una sentencia judicial que declaraba improcedente la expropiación, en virtud de los artículos transitorios de esta nueva ley, la resolución judicial quedaba como letra muerta.

La aplicación de la Ley $\mathrm{N}^{\circ} 16.640$ produjo la presentación de numerosos recursos de inaplicabilidad ante la Corte Suprema, los que fueron invariablemente rechazados al considerar que no se vulneraba los preceptos constitucionales ${ }^{126}$. Pensamos que la mayoría de los ministros de la Corte estuvieron por evitar un conflicto con el Poder Legislativo, y consecuencialmente, con el Ejecutivo, no obstante la clara intencionalidad política de la legislación transitoria específica que se había aprobado.

No cabe duda que, frente a numerosos fallos judiciales que estaban declarando la improcedencia de ciertas expropiaciones, la reacción fue el envío y aprobación de un texto legislativo que permitía al Ejecutivo aplicar un nuevo criterio para la fijación de la indemnización, así como proceder con las expropiaciones.

Tanto es así, que la Corte Suprema, aún deslizando que tal disposición normativa podía ser injusta, optó por declararla constitucional. "Que cualesquiera que fueren las críticas que a esta disposición pudieran formularse desde el punto de vista de la justicia y la equidad, y aun si se aceptara que este articulo envuelve un desconocimiento de los derechos de los propietarios de los predios cuya expropiación fue rechazada, al permitir una nueva expropiación, sin que se hubieren modificado las circunstancias de hecho en que se fundamentó el fallo absolutorio para su parte, es lo cierto que no puede sostenerse que el precepto legal objetado al otorgar esta facultad al organismo correspondiente, invada las atribuciones constitucionales de la Judicatura y, en consecuencia, no vulnera el artículo 80 de la Constitución Politica del Estado"127.

Resulta sorprendente cómo el máximo tribunal del país, no obstante constatar que la aplicación de la norma transitoria establecida en el artículo 3 de la Ley $\mathrm{N}^{\circ} 16.640$ constituía un desconocimiento de los derechos de ciertos propietarios sobre sus predios, decidiera rechazar los recursos por

${ }^{125}$ Ibíd., p. 33.

${ }^{126}$ Véase en este sentido otros recursos de inaplicabilidad rechazados en Revista de Derecho y Jurisporudencia, 65 (Santiago, 1968) 1, $1^{\text {a }}$ parte, sección $1^{\text {a }}$, pp. 45 y 78.

${ }^{127}$ Corte Suprema, 12 de enero de 1968, en Revista de Derecho - Gaceta de los Tribunales (Santiago, 1968) Tomo 65, N¹, Parte Segunda, Sección Primera, p.76. 
ellos interpuestos por una simple interpretación formalista de la función del recurso de inaplicabilidad.

Pensamos que en este caso, la Corte hizo una total y completa abstracción de la realidad política y social que vivía el país, optando por evitar el conflicto con el resto de los poderes del Estado, a diferencia de los ministros disidentes del mismo Tribunal, que en estas causas dejaron idénticas constancias de sus votos al considerar vulnerada la independencia del Poder Judicial.

4. Ocupaciones ilegales.

El derecho de propiedad consagrado en la Constitución Politica fue foco de conflicto durante el período investigado, al enfrentarse a los procesos de reforma agraria, requisiciones, y expropiaciones; y también a las "tomas" y ocupaciones ilegales. La labor de protección de este derecho desplegado por el Poder Judicial no fue del todo pacífica, en tanto muchos de sus fallos fueron interpretados políticamente como parte de una estrategia de oposición a la ejecución del programa de gobierno de la Unidad Popular.

Así, conociendo de un recurso de queja interpuesto en contra de los ministros de una sala de la Corte de Apelaciones de Santiago, la Corte Suprema efectuó un análisis del momento que se vivía en relación al respeto al derecho de propiedad, instruyendo, en forma inédita, al resto de los Tribunales del país acerca del mejor modo de concurrir a su protección. "Que, sin embargo, en la actualidad tal situación adquiere caracteres de importancia si se tiene en cuenta la frecuencia con que se denuncian las ocupaciones ilegales de bienes inmuebles, y los requerimientos consiguientes de los propietarios que solicitan su restitución y las indemnizaciones correspondientes./ Ello ha movido a esta Corte a instruir a los tribunales para que presten especial atención a los procesos que se siguen por el delito de usurpación, actuando con la mayor diligencia y celeridad en la instrucción de los mismos" 128.

Y en lo que parecía un claro mensaje al Ejecutivo, empeñado en llevar adelante su programa de gobierno, la Corte remarcó: "Que mientras se mantenga en nuestro pais el régimen de propiedad privada que determinan la Constitución y las leyes, es obligación primordial de los tribunales -como corresponde hacerlo en un estado de legalidad - prestar, también, la debida protección a los derechos referentes al dominio de los inmuebles cuando se encuentran amagados" 129 .

El 24 de abril de 1972 el juez del Séptimo Juzgado del Crimen de Santiago, conociendo de una querella por usurpación interpuesta por un industrial cuya

${ }^{128}$ Corte Suprema, 26 de julio de 1972, en Fallos del Mes, año XIII, 164 (Santiago, 1972), p.150

${ }^{129}$ Ibíd., p. 150. 
empresa llevaba 15 días ocupada por sus trabajadores, acudió directamente a Carabineros, obligándoles a que le concedieran el auxilio de la fuerza pública, efectuando el desalojo de sus ocupantes ${ }^{130}$.

Una situación similar es la que determinó el Juez del Cuarto Juzgado Civil en la causa seguida por la industria textil Rayón Said S.A.. El Ministerio de Economía había fundado la requisición en la circunstancia de haber estallado una huelga en dicha industria junto a otras siete del área textil, de la que se derivó una "toma” por parte de sus trabajadores, haciendo previsible un posible desabastecimiento. El Juez afirmó que la huelga había sido ilegal; que la ocupación del inmueble estaba tipificada como delito de usurpación en el Código Penal, y que el desabastecimiento no existía al momento de decretarse la medida de requisición. "[...] si se admitiera lo que el sentenciador no acepta, que un organismo del Estado pudiera fundar sus decisiones en circunstancias de carácter delictivo, ello significaría reconocer la falta de vigencia del Estado de derecho, cuyo respeto es, precisamente, la finalidad primordial de la jurisdicción"131.

Más aún, el mismo magistrado abordaba la realidad política del momento y develaba la verdadera motivación tras la requisición decretada, al sostener que "es un hecho de público y notorio conocimiento que el Estado por medio de sus diversos organismos administrativos ha manifestado, enfáticamente, a través de todos los sistemas de comunicación, su intención de mantener las requisiciones decretadas, no devolver a sus propietarios los bienes afectados por aquéllas, para mediante tal modus operando, llegar a constituir lo que se ha dado en denominar el área de propiedad social"132.

\section{El recurso de queja.}

Uno de los casos emblemáticos, tanto por el grupo empresarial afectado, como por el insospechado conflicto entre poderes del Estado que de él se derivó, fue la requisición del uso y goce del establecimiento industrial, comercial y maquinarias de Manufactureras Chilenas de Algodón Yarur.

El 23 de julio de 1972 el director nacional de Industria y Comercio decidió la requisición de esta industria, incluidos sus elementos necesarios para la producción y distribución; el uso y goce de los locales; y la mercadería y materias primas que en el se encontraban. Procedió asimismo a designar a dos interventores con amplias atribuciones.

${ }^{130}$ Arriagada, Genaro, cit. (n. 44), p. 182.

${ }^{131}$ CUARTO JUZGado EN LO CIVIL DE MAYOR CUANTÍa (1972), citado por Arriagada, Genaro, cit. (n. 44), p. 182. Por falta de antecedentes no se ha podido acceder al texto original de la sentencia citada por el autor.

${ }^{132}$ Ibíd., p. 182. Por falta de antecedentes no se ha podido acceder al texto original de la sentencia citada por el autor. 
Sus propietarios apelaron de esta decisión ante el mismo Director, quien declaró inadmisible tal recurso; insistiendo mediante recurso de hecho ante el tribunal especial de segunda instancia que contemplaba la Ley $\mathrm{N}^{\circ} 17.066$, en cuya virtud se declaró la requisición, el que, sin embargo, también fue rechazado.

En contra de los miembros de este Tribunal de Comercio, el señor Yarur interpuso ante la Corte Suprema un recurso de queja solicitando se dejara sin efecto esta última resolución, y en su reemplazo, se declarara procedente el recurso de apelación.

El máximo tribunal acogió el recurso de queja por sentencia de fecha 4 de enero de 1972, rechazando la tesis del Ejecutivo en el sentido que la requisición era un acto administrativo, razón por la cual el afectado no podía reclamar el Tribunal de Comercio; y que en contra de las resoluciones de éste último no cabía reclamar ante la Corte Suprema. "[...] es incontrarrestable que la interpretación restringida que los recurridos dan a la procedencia del recurso de apelación no se ajusta a los términos de la ley. El amplio derecho para recurrir de apelación no tiene limitación alguna y de tenerla, sólo podría emanar de la misma ley; por ello, al negar lugar al recurso de hecho interpuesto contra la resolución del Director que declaró improcedente la apelación, han inferido al recurrente un agravio que corresponde enmendar por el presente recurso"133.

El reconocimiento que la Corte Suprema hizo de su jurisdicción y competencia sobre los organismos públicos encargados de las requisiciones marcó un fuerte punto de conflicto con el Ejecutivo, quien planteó desde el inicio el carácter decisivo que este asunto tenía para la constitución de la llamada área social ${ }^{134}$.

En efecto, el Gobierno defendía la tesis de la incompetencia de la Corte frente a los Tribunales Administrativos, los que, por tanto, no estaban sujetos a la superintendencia directiva, correccional y económica que la Constitución y el Código Orgánico de Tribunales le conferían ${ }^{135}$. Esto dejaba vía libre para que dichos órganos administrativos, afines al Gobierno, pudieran ejecutar los decretos que servían de base para la implementación del programa de expropiaciones y requisiciones de la Unidad Popular.

\section{Reacciones y ataQues}

\section{Protectores del régimen vigente.}

Una manifestación adicional de la posición crítica del Poder Judicial, a

${ }^{133}$ Corte Suprema, 4 de enero de 1972, en Fallos del Mes, Año XIII, 158 (Santiago, 1972) p. 332.

${ }^{134}$ ARriagadA, Genaro, cit. (n. 44), p. 180.

${ }^{135}$ Brahm, Enrique, cit. (n. 24), p. 236. 
través de sus fallos, como la hemos venido describiendo, la constituyen las reacciones de ciertos sectores de la dirigencia, quienes pasaron de la crítica política, al ataque frontal contra el máximo Tribunal del país, en corto tiempo.

Así, el Partido Socialista formuló en 1967 graves acusaciones en contra de la Corte Suprema, con ocasión del libelo constitucional interpuesto en contra de sus integrantes, tildándola de ser un justicia clasista y burguesa. A su juicio, sus magistrados habrían adherido a la clase dominante, y con su actuación adversa a los intereses de la Nación, se habrían hecho merecedores del "repudio y la desconfianza de la mayoría abrumadora de la ciudadanía"136.

Y para demostrar la evolución de este comportamiento, el senador socialista Aniceto Rodríguez ilustraba durante la exposición de la acusación constitucional, que ya en 1962, el senador Renán Fuentealba escribía a don Sergio Recabarren, que "respecto de sus observaciones de fondo sobre la administración de Justicia y su cada vez mayor dependencia de ciertos intereses sociales dominantes, vale la pena reflexionar. Los Tribunales están comprometidos a presiones sociales e influencias politicas y no son sino el reflejo de las condiciones de vida de un orden llamado a desaparecer"137.

Más aún, en opinión del Comité Central del Partido Socialista, la Corte Suprema, a través de su jurisprudencia, "ha ido interpretando la ley con espiritu retrógrado, tergiversando la letra y el propósito de la ley, anulando su contenido progresista" 138 .

En este mismo sentido reaccionaba el editorial de la revista Punto Final, al sostener que el fallo de la Corte Suprema que concedió el desafuero al senador Altamirano, obedecía a una "ofensiva iniciada en contra del movimiento revolucionario por la clase gobernante, la burguesía”, y que estaría compuesto por el Gobierno, las Fuerzas Armadas y los tribunales ${ }^{139}$.

Más aún, el editorialista sentenciaba que el "principal deber, entonces, es enfrentar el Poder Burgués y luchar por reemplazarlo por un Poder Popular. Las reglas del juego las está rompiendo la clase dominante, y es ingenuo invocar normas que el adversario no está dispuesto a respetar" 140.

En esta misma revista, otro columnista apoyaba la tesis de que el Máximo Tribunal había asumido como misión la defensa del sistema imperante, identificándose con la clase dominante. "Por eso manejan la ley con un sentido conservador. Sus fallos tienden a salvaguardar el régimen y los intereses de la clase que representan. Toda legislación que pretende innovar, restringir los

\footnotetext{
${ }^{136}$ Rodríguez, Aniceto, cit. (n. 95), p. 413.

${ }^{137}$ Ibíd.

${ }^{138}$ Ibíd., p. 414.

${ }^{139}$ El Poder Burgués (anónimo), en Punto Final, Año II, 38 (Santiago, 1967), p. 1.

${ }^{140}$ El Poder Burgués, cit. (n. 139), p. 1.
} 
privilegios o debilitar las instituciones o principios en que descansa la estructura social, se estrella contra la incomprensión de la Corte Suprema"141.

De esta forma, lo que había comenzado como una crítica al modo de interpretar la ley, pronto devino en una abierta acusación de politización en contra de la cabeza del Poder Judicial. El fallo que desaforó a Carlos Altamirano fue recibido por aquellos que se declaraban partidarios de los cambios revolucionarios en el país, como una agresión y una provocación a todo el movimiento popular de pensamiento marxista, acusando a la Corte de abanderizarse frente a un problema político, mediante una "resolución tan politica y tan poco jurídica"142.

\section{Justicia de clases.}

La idea de un Poder Judicial al servicio de las clases dominantes y como protectores del status vigente, fue defendida por el principal asesor legal del presidente Allende, Eduardo Novoa Monreal: "Cada día se extiende más la imputación de que en Chile se administra una justicia de clase. Esto significa atribuir a los jueces una concepción unilateral de la justicia -puesto que la concebirian únicamente como aquello que es útil para el sostenimiento del status social vigente - y a la vez coloca a los tribunales en abierto antagonismo con todos los sectores, cada vez más amplios, que creen indispensables profundos cambios sociales" 143 .

El concepto de justicia de clases ya había sido utilizado políticamente en contra de la Corte Suprema con ocasión de la acusación constitucional en contra del senador Altamirano. Sin embargo, fueron las imputaciones de Novoa las que más reacciones provocaron.

Varias fueron las causas que, a juicio del presidente del Consejo de Defensa del Estado, determinaron que la justicia en Chile se hiciera acreedora de tal apelativo. En primer lugar, "el Poder Judicial chileno no ha logrado adaptarse a las circunstancias sociales que vive el pais"; "el pluralismo ideológico imperante no rige para el Poder Judicial, mantenido enteramente al margen de la renovación de las aspiraciones nacionales en lo social ${ }^{144}$.

Más aun, según Novoa, para llegar a ser miembros de este poder del Estado, se exigía adherir a las posiciones tradicionalistas y de conformismo social, así como también debían pertenecer a los sectores conservadores ${ }^{145}$.

${ }^{141}$ FaIvovich, Jaime, La reacción tiene santos en la Corte, en Punto Final, 38 (Santiago, 1967) año II, p.2

${ }^{142}$ Faivovich, Jaime, cit. (n. 141), p. 3.

${ }^{143}$ Novoa Monreal, Eduardo, ¿Justicia de clase? en Mensaje, 187 (Santiago, 1970), p. 108

${ }^{144}$ Ibíd., p. 117.

${ }^{145}$ Ibíd., p. 118. 
El destacado jurista avanzó un paso más en esta crítica. Ya no se trataba sólo de reprochar una determinada interpretación de las normas vigentes, sino que atribuía el comportamiento de la Corte Suprema a una cuestión de origen social, adhiriéndose a la tesis que predicaba la lucha de clases. Lo anterior le llevará a sostener que "es tal el peso de su extracción, de suformación, del medio en el que se desenvuelven y de los estimulos psicológicos que reciben normalmente en su desempeño, que difícilmentellegarán siquiera a interrogarse si no habrá otra manera diferente de administrar justicia" 146.

En segundo lugar, Novoa sostenía que la Corte Suprema desbordó sus atribuciones y dictó resoluciones que escapaban a las reglas procesales, revisándose sentencias contra las que no procedían recursos, o alterando su contenido sin oír a todos los interesados, u olvidando la aplicación de la cosa juzgada derivada de fallos ejecutoriados, lo que determinó -a su juicio- la prescindencia de las reglas del derecho, no existiendo autoridad alguna ante la cual reclamar ${ }^{147}$.

Por último, agravaba la tendencia del máximo Tribunal, la circunstancia de haberse establecido la completa irresponsabilidad de sus miembros, lo que "permite la impunidad de eventuales transgresiones de la ley en que los ministros de la Corte Suprema pudieran incurrir"148.

Esta concepción de la justicia es la que llevaba a Novoa a sostener que "sólo podremos hablar, por eso, de una verdadera Justicia, en cuanto los encargados de aplicarla sean capaces de imponer una auténtica justicia social, que es la más excelsa expresión de la juridicidad de una sociedad humana"149.

Frente a estas aseveraciones, el pleno de la Corte Suprema emitió un pronunciamiento formal, haciendo suyas las palabras que su presidente pronunciara al inaugurar el año judicial, en el sentido que el Poder Judicial era un simple aplicador de las leyes vigentes, por lo que era "necesario que los cuerpos legislativos estudien los cambios que el progreso de la legislación requiere a fin de que se obtenga un efectivo mejoramiento en los sistemas imperantes y se atiendan todas aquellas necesidades que la Justicia exige para un mejor servicio de la comunidad"150.

Siendo doctrina común lo que la Corte sostenía, lo que verdaderamente estaba en discusión era si este poder del Estado debía o no defender el Estado de Derecho. Por ello sostenía un editorial de El Mercurio que "esta acerba campaña tiene una inspiración politica clara, y son estériles los intentos

\footnotetext{
${ }^{146}$ Ibíd.

${ }^{147}$ Ibíd.

${ }^{148}$ Ibíd.

${ }^{149}$ Ibíd.

${ }^{150}$ Corte Suprema, La Corte Suprema analizó criticas a la Justicia, en El Mercurio (Santiago, 15 de abril de 1970) p 25.
} 
de revestirlas de un barniz jurídico. Lo que se desea es el desprestigio de una institución que hace respetar la ley y que es una garantía eficazpara la preservación en Chile del estado de Derecho, para aclimatar en cambio una estructura judicial propia de los regímenes dictatoriales, en que los jueces fallan bajo la consigna politica"151.

\section{El enfrentamiento.}

Entre los años 1971 y 1972 aumentaron considerablemente las tomas de propiedades como una forma de apurar las expropiaciones a cargo del Consejo de la Corporación de la Reforma Agraria (CORA).

Frente a las mismas, algunos propietarios que sentían burlados sus derechos, solicitaban al Tribunal Agrario, algunos de cuyos miembros pertenecían al Poder Judicial, la concesión de medidas precautorias con el fin de suspender los efectos de la expropiación por al menos 50 días, prorrogables. Otros, en cambio, interpusieron querellas por usurpación, daño y robo, en contra de quienes efectuaban las "tomas", algunos de los cuales terminaban presos por la misma razón ${ }^{152}$.

Así comentaba Ernesto Carmona en la revista Punto Final las consecuencias de las tomas en Conchalí en julio de 1972, y la reacción de sus propietarios: "quizá cuándo se tomará posesión [en una de las hijuelas del Huanaco] porque tiene 'medida precautoria', que es una nueva 'chiva legal' descubierta por los patrones [...]. La 'medida precautoria' es otorgada por el Tribunal Agrario, integrado por cinco miembros, tres de los cuales representan al Poder Judicial. El latifundista apela de la expropiación, afirmando que el fundo no estaba abandonado o cualquier otro pretexto y el Tribunal Agrario inmediatamente otorga la 'medida precautoria' que paraliza la toma de posesión por 50 dias que pueden ser prorrogados"153.

En protesta por estas resoluciones, y según comenta el mismo columnista, "los campesinos de Conchali participaron en el mitin que el Partido Socialista organizó el miércoles 12 de julio en la Plaza Montt-Varas, frente al Palacio de los Tribunales y el Congreso Nacional" ${ }^{154}$, lo que motivó una enérgica protesta de la Corte Suprema al jefe de Estado "y, especialmente, contra la autoridad que permitió una reunión que, desde su iniciación clandestina, sólo demostró tener, entre otros, el propósito de denostar y hasta insultar al Poder Judicial, cuy a sede más alta está, precisamente, frente al lugar escogido para el acto público mencionado, [...] y le pide que no solo ordene sino que haga cumplir por dicha

${ }^{151}$ Críticas al Poder Judicial, en El Mercurio (Santiago, 16 de abril de 1970), p. 3.

${ }^{152}$ Cfr. Carmona, Ernesto, En Conchali los jueces también son latifundistas, en Punto Final, año VI, 163 (Santiago, 1972) p.18-19.

${ }^{153}$ Ibíd., p. 18.

${ }^{154}$ Ibíd., p. 19. 
autoridad la obligación de velar por el libre ejercicio de la Magistratura y el desarrollo normal de las funciones judiciales, porque no es posible que tan alta función sea entrabada por manifestaciones tumultuarias irresponsables"155.

Esta manifestación constituyó el primer acto de fuerza en contra del Poder Judicial, no reprimido por el Ejecutivo, precedido de algunas "tomas" esporádicas de Tribunales de Justicia, como fueron la Corte de Apelaciones de Talca y el Juzgado de Melipilla ${ }^{156}$.

La política de los resquicios legales había encontrado serios obstáculos en las sentencias judiciales que acogieron recursos de queja, ordenaban la devolución de industrias a sus propietarios, decretaban la ilegalidad de expropiaciones, mandaban el desalojo de las "tomas", entre otras. "Era la muerte definitiva de los resquicios, pero, por sobre todo, la vuelta atrás en el área social"157.

El conflicto entre el Ejecutivo y el Judicial encontró su punto máximo en el ya conocido intercambio de oficios entre el presidente de la República y la Corte Suprema en junio de 1973, en el que ésta última, utilizando un lenguaje nunca antes visto, reprochaba al jefe de Estado por "cambiar el pedestal del Poder Supremo en que la ciudadanía y, por consiguiente, esta Cortelo tenía colocado, por la precaria posición militante contra el órganojurisdiccional superior del país, que por imperativo del deber, tiene que contrariar a veces en sus fallos los deseos más fervientes del Poder Ejecutivo"158.

Así, la Corte Suprema decidió en su respuesta abordar pormenorizadamente el contenido y afirmaciones que el presidente Allende vertió en el oficio a ella dirigida con fecha 12 de junio de $1973^{159}$, entrando de lleno en el campo político y manifestando abiertamente su oposición a las políticas del Gobierno: "Primero hay que responder que la 'solicitud y entusiasmo inusuales' de parte de los jueces, corren a parejas con similares cualidades de la administración para hacer las requisiciones, o de los interventores para girar contra las cuentas corrientes y vender; [...] tendría explicación adecuada en la necesidad de los jueces de satisfacer en justicia las peticiones de los querellantes

${ }^{155}$ Corte Suprema, Protesta hechos frente a Tribunales, en Libro de Actas de Acuerdos del Pleno de la Corte Suprema, 47 (Santiago, 13 de julio de 1972), p. 203.

${ }^{156}$ Véase: Corte Suprema, Necesidad de acatamiento de decisiones judiciales por autoridades administrativas. Representación a S.E. el Pdte. de la Rep., en Libro de Actas de Acuerdos del Pleno de la Corte Suprema, 79 (Santiago, 30 de octubre de 1972), pp. 264 ss.

${ }^{157}$ Arriagada, Genaro, cit. (n. 44), p. 251.

${ }^{158}$ Corte Suprema, Respuesta al Presidente de la República, en Libro de Actas de Acuerdos del Pleno de la Corte Suprema, 33 (Santiago, 25 de junio de 1973), p. 53.

${ }^{159}$ Véase Presidente de la república, Oficio del Presidente de la República a la Corte Suprema en relación al cumplimiento de la órdenes judiciales, en ECHEVERRÍA, Luis - FREI, Luis, cit. (n. 12), III, p. 163. 
destinados a atajar el excesivo uso en que se fundan de los llamados resquicios legales y en la liberalidad excesiva que alegan de los interventores para sus inversiones financieras en las empresas intervenidas" 160.

La Corte Suprema calificaba la legitimidad de las decisiones políticas del Ejecutivo, preguntándole derechamente al jefe de Estado: “PPretende el oficio de V.E. que los Tribunales de Justicia olviden la ley, prescindan de todos los principios y en nombre de una justicia social sin ley, arbitraria, acomodaticia $y$ hasta delictuosa en su caso, amparen incondicionalmente a los tomadores y repudien de la misma manera a los que pretenden la recuperación de suspredios tomados?"161.

El juicio de reproche jurídico y político que la Corte efectuó al presidente Allende no podía ser más explícito; y en el intento por generar una reacción frente al desconocimiento de sus prerrogativas más esenciales, el Poder Judicial recibió un nuevo golpe, al serle devuelto éste último oficio mediante carta del Secretario General de Gobierno, por haberse considerado irrespetuoso, inconveniente, improcedente e inaceptable ${ }^{162}$.

\section{CONCLUSIONES}

El análisis precedente nos permite sostener que la falta de entendimiento entre el poder Ejecutivo y el Congreso para la ejecución del programa de gobierno, tanto de Frei Montalva como de Allende, determinó que el contrapeso efectivo entre los poderes del estado en un régimen presidencial como el nuestro, fuera ejercido por el Poder Judicial.

Sólo así se entiende que a la discusión política le siguiera una de orden legal y jurídico. La sede natural para la implementación de acuerdos entre las distintas fuerzas políticas debieron ser los partidos políticos y el Congreso. Y sin embargo, al no darse esos acuerdos y, en cambio, polarizarse las posiciones, el Ejecutivo buscó los necesarios instrumentos para ejecutar sus promovidas reformas, con total autonomía.

En este escenario, y frente a una oposición imposibilitada de ejercer su papel fiscalizador en la discusión legislativa, la independencia del Poder Judicial se mostró cómo último recurso para contrarrestar la ofensiva del Ejecutivo por poner en marcha sus planes revolucionarios.

Se enfrentaron así la legalidad formal con el especial contenido que los gobiernos entre 1965 y 1973 quisieron darle, determinando un choque

${ }^{160}$ Corte Suprema, cit. (n. 158), p. 65.

${ }^{161}$ Ibíd., p. 73.

${ }^{162}$ Secretario General de Gobierno, Carta del Secretario General de Gobierno devolviendo oficio de la Corte Suprema, en Echeverría, Luis - Frei, Luis, cit. (n. 12), III, p. 198. 
interpretativo con la oposición, y cuya resolución fue entregada al Poder Judicial. Desde esta perspectiva, no cabe duda que el conflicto que se sometió a conocimiento de los tribunales tenía un marcado sentido político, desde el momento en que lo que trasuntaba el mismo era la posibilidad de llevar adelante un programa de gobierno que postulaba reformas encaminadas a promover una revolución.

Prueba de lo anterior es la evolución del conflicto entre el Ejecutivo y la Corte Suprema. El recurso del presidente Allende a los denominados "resquicios legales" llegó cuándo éste no logró obtener los apoyos necesarios para la aprobación legislativa de sus reformas. Por lo tanto, los cambios a la legalidad vigente los intentó a través de decretos del Ejecutivo, encontrándose, sin embargo, con un obstáculo: los fallos judiciales adversos.

Frente a ellos, primero se discrepó públicamente del contenido de los fallos que no avalaban la tesis del Gobierno; para luego dar paso a la crítica directa, a la presión mediante una acusación constitucional interpuesta en contra del pleno de la Corte Suprema -y que tuvimos ocasión de revisar-, al agravio y ataque frontal, incluidas manifestaciones callejeras de los partidarios del Gobierno, "medio de presión tradicional durante el régimen de la unidad Popular"163, para terminar con un quiebre irremediable. "Se producía así el desenlace de una larga batalla jurídico-política librada en los tribunales, dando lugar a un conflicto frontal entre el Poder Ejecutivo y la Corte Suprema, a la que la Unidad popular descalificó con singular violencia, originándose un nuevo fenómeno de deslegitimación por parte de un sector político relevante de una de las instituciones fundamentales del país"164.

Sin embargo, creemos que no es posible sostener que el Poder Judicial hubiera planificado una intervención tan directa y definitiva como la que en la realidad ocurrió. Los fundamentos de los fallos que analizamos precedentemente, dan cuenta de una búsqueda de protección de principios que este poder del Estado consideraba formaban parte esencial del estado de Derecho y de la estabilidad del ordenamiento jurídico. Y si bien la interpretación contendida en esas sentencias trajeron aparejadas indudables consecuencias políticas, éstas se debieron a que afectaba directamente al mecanismo que el Gobierno había ideado para implementar su programa político.

Por ello, no compartimos lo sostenido por Boeninger, en el sentido que en esta larga confrontación "el sistema jurídico se politizó en tal grado que jueces y abogados por igual estaban identificados con alguno de los bandos en pugna. [...]. Una polarización política tan extrema como la que vivía el país tenía, inevitablemente, que perforar la capacidad de cualquier institución

\footnotetext{
${ }^{163}$ BrAHM, Enrique, cit. (n. 24), p. 236.

${ }^{164}$ Boeninger, Edgardo, cit. (n. 29), p. 203.
} 
de cumplir con sus funciones con la objetividad o prescindencia política requerida"165.

Una cosa son los fallos judiciales en materias como expropiaciones, tomas de fundos, requisiciones, etc., cuyos fundamentos fueron jurídicos, aunque cumplieron un papel político por sus consecuencias; y una cosa diferente es la defensa que la Corte Suprema efectuó de sus prerrogativas y funciones esenciales como Poder del Estado y que la Constitución le reconocía, y que, a su juicio, no eran respetadas por el jefe de Gobierno. Efectivamente, el contenido de los oficios intercambiados entre las máximas autoridades del Ejecutivo y el Judicial, revelan una politización radical, pero no ya en la defensa de los intereses de particulares, sino en los propios institucionales.

Por ello, podemos decir que si bien el conflicto entre estos poderes del Estado tuvo su origen en una diversa interpretación de las normas jurídicas aplicables a controversias de particulares con el Fisco, y que trajo como consecuencia la obstaculización de la ejecución del programa de gobierno respectivo, la reacción de éste último fue el ataque frontal al poder Judicial, en un intento por deslegitimarlo para restarle valor a su función. Y esa reacción es la que encontró una defensa igualmente dura y política en manos de los altos magistrados.

\section{BiBLIOGRAFÍA}

Fuentes:

Consejo General de la Orden de Abogados, Antecedentes Histórico Jurídicos: Años 19721973 (Santiago, Editorial Jurídica de Chile, 1980).

Diario de Sesiones de la Cámara de Diputados.

Diario de Sesiones del Congreso Pleno.

Diario de Sesiones del Senado.

Ley $\mathrm{N}^{\circ} 12.927$ de Seguridad del Estado.

Libro de Actas de Acuerdos del Pleno de la Corte Suprema.

Programa de la Unidad Popular (Santiago, 1969).

\section{Literatura:}

Altamirano Orrego, Carlos, La lucha armada en América Latina, en Punto Final, Suplemento 31 (Santiago, 1967).

Arriagada Herrera, Genaro, De la "Via Chilena" a la "Via Insurreccional" (2a edición, Santiago, Editorial del Pacífico, 1974).

Boeninger, Edgardo, Democracia en Chile. Lecciones para la gobernabilidad (2a edición, Santiago, Editorial Andrés Bello, 1997).

Brahm García, Enrique, Propiedad sin Libertad: Chile 1925-1973. Aspectos relevantes en el avance de la legislación socializadora (Santiago, Universidad de los Andes, 1999).

${ }^{165}$ Ibíd. 
Brahm, Enrique - Bertelsen, Raúl - Amunátegui, Andrés, Régimen de Gobierno en Chile. ¿Presidencialismo o Parlamentarismo? 1925-1973 (Santiago, Editorial Jurídica de Chile, 2002).

Bravo Lira, Bernardino, El juez entre el Derecho y la ley, en el mundo hispánico (Santiago, LexisNexis, 2006).

Bravo Lira, Bernardino, La crisis de la idea de Estado en Chile, durante el siglo XX, en Góngora, Mario (autor), Ensayo Histórico sobre la Noción de Estado en Chile en los siglos XIX y XX, (7ª edición, Santiago, 1984), anexo 3.

Bravo Lira, Bernardino, Los estudios sobre la Judicatura Chilena de los siglos XIX y XX, en Revista de Derecho y Jurisprudencia, 51-52 (Santiago, 1992).

Bravo Lira, Bernardino, Presidente y Estado de Derecho en Chile. Estudio históricoinstitucional, en Revista de Derecho y Jurisprudencia, 95 (Santiago, 1993) 2.

Brunner, José Joaquín, Comentarios nacionales, en Mensaje, 1 (Santiago, 1968).

Cardemil, Alberto, El Camino de la utopía. Alessandri, Frei, Allende. Pensamiento y obra (Santiago, Editorial Andrés Bello, 1997).

Carmona, Ernesto, En Conchali los jueces también son latifundistas, en Punto Final, Año VI, 163 (Santiago, 1972).

Correa, Sofía y otros, Historia del siglo XX chileno. Balance Paradojal (4a edición, Santiago, Editorial Sudamericana, 2008).

Cortés Alvear, Loreto, La Corte Suprema de Justicia y sus relaciones con el Poder Ejecutivo durante el gobierno de la Unidad Popular (1970-1973) (Tesis para optar al grado de licenciada en Ciencias Jurídicas Pontificia Universidad Católica de Chile, Santiago, inédito, disponible en Biblioteca Facultad de Derecho Pontificia Universidad Católica de Chile, 1992).

Cumplido, Francisco - Balbontín, Ignacio, Proyecto de cambio e institucionalidad jurídico-politica. Chile 1964-1973, en Documento de Trabajo FLACSO, 72/78 (Santiago, 1978).

ECheverría, Luis - Frei, Luis (editores), La lucha por la juridicidad en Chile 19701973 (Santiago, Editorial del Pacífico, 1974).

Faivovich, Jaime, La reacción tiene santos en la Corte, en Punto Final, Año II, 38 (Santiago, 1967).

Fontaine Aldunate, Arturo, Todos querian la Revolución. Chile 1964-1973 (Santiago, Empresa Zig-Zag S.A., 1999).

Frei Montalva, Eduardo, Proyecto sobre Leyes Normativas, en Politica y Espiritu, 287 (Santiago, 1964).

GARCÉs, Joan, Via insurreccionaly via politica: dos tácticas, en Revista de la Universidad Técnica del Estado, 13-14 (Santiago, 1973).

Góngora del Campo, Mario, Ensayo histórico sobre la noción de Estado en Chile en los siglos $X I X$ y XX (7a edición, Santiago, Editorial Universitaria, 1998).

Illanes BeníteZ, Osvaldo, Memoria leida por el Presidente de la Excma. Corte Suprema en la Sesión Inaugural del año 1969, en Revista de Derecho, Jurisprudencia y Ciencias Sociales y Gaceta de los Tribunales, 66 (Santiago, 1969) 1.

Moulian Emparanza, Tomás, Fracturas: De Pedro Aguirre Cerda a Salvador Allende (1938-1973) (Santiago, LOM Ediciones, 2006).

Novoa Monreal, Eduardo, El difícil camino de la legalidad, en Revista de la Universidad Técnica del Estado, 7 (Santiago, 1972).

Novoa Monreal, Eduardo, Los resquicios legales. Un ejercicio de lógica jurídica (Santiago, Editorial Bat, 1992). 
Novoa Monreal, Eduardo, Vias legales para avanzar hacia el Socialismo, en Revista de Derecho Económico, 33-34 (Santiago, 1971).

Vial Correa, Gonzalo, Salvador Allende: El fracaso de una ilusión, (Santiago, Centro de Estudios Bicentenario, 2005). 
